\title{
Regulation of soluble guanylate cyclase by matricellular thrombospondins: implications for blood flow
}

\author{
Natasha M. Rogers' ${ }^{1}$, Franziska Seeger ${ }^{2}$, Elsa D. Garcin' ${ }^{2}$, David D. Roberts ${ }^{3}$ and Jeffrey S. Isenberg ${ }^{1,4 *}$ \\ ' Department of Medicine, Vascular Medicine Institute, University of Pittsburgh School of Medicine, Pittsburgh, PA, USA \\ ${ }^{2}$ Department of Chemistry and Biochemistry, University of Maryland Baltimore County, Baltimore, MD, USA \\ ${ }^{3}$ Laboratory of Pathology, Center for Cancer Research, National Cancer Institute, NIH, Bethesda, MD, USA \\ ${ }^{4}$ Department of Medicine, Division of Pulmonary, Allergy and Critical Care Medicine, University of Pittsburgh School of Medicine, Pittsburgh, PA, USA
}

\section{Edited by:}

Thomas Rich, University of South Alabama College of Medicine, USA

Reviewed by:

Pascal Bernatchez, University of British Columbia, Canada

Amanda Jo LeBlanc, University of Louisville, USA

\section{*Correspondence:}

Jeffrey S. Isenberg, University of Pittsburgh School of Medicine, BST, Room E1258, 200 Lothrop Street,

Pittsburgh, PA 15261, USA

e-mail: jsi5@pitt.edu
Nitric oxide (NO) maintains cardiovascular health by activating soluble guanylate cyclase (sGC) to increase cellular cGMP levels. Cardiovascular disease is characterized by decreased NO-sGC-cGMP signaling. Pharmacological activators and stimulators of sGC are being actively pursued as therapies for acute heart failure and pulmonary hypertension. Here we review molecular mechanisms that modulate sGC activity while emphasizing a novel biochemical pathway in which binding of the matricellular protein thrombospondin-1 (TSP1) to the cell surface receptor CD47 causes inhibition of sGC. We discuss the therapeutic implications of this pathway for blood flow, tissue perfusion, and cell survival under physiologic and disease conditions.

Keywords: soluble guanylate cyclase, cyclic guanosine monophosphate, thrombospondin-1, CD47, nitric oxide, cardiovascular disease, ROS

\section{INTRODUCTION}

Cardiovascular disease is the number one cause of death worldwide and remains a burdensome health problem. Understanding the underlying molecular mechanisms of cardiovascular disease will provide valuable information for the design of novel drugs for pharmacological therapies.

As a central player of the canonical NO-sGC-cGMP pathway, sGC controls important physiological functions such as smooth muscle relaxation, platelet aggregation, and hemostasis (Isenberg et al., 2009b). Hence, sGC activity is a primary means of controlling acute and chronic blood flow. The gaseous molecule NO directly activates $\mathrm{sGC}$ and increases the production of the signaling molecule $3^{\prime}, 5^{\prime}$-cyclic GMP (cGMP) from GTP several hundred fold (Arnold et al., 1977). Second messenger cGMP, in turn, targets the contractile apparatus of arterial smooth muscle cells and adhesive pathways of platelets and inflammatory cells to promote vasodilation and disadhesion/disaggregation (Murad et al., 1985; Munzel et al., 2003). Decreased NO bioavailability and sGC oxidation lead to inefficient $\mathrm{sGC}$ activation and lower cGMP output, which are associated with and directly contribute to cardiovascular diseases including ischemic heart disease, decompensated heart failure, ischemia reperfusion injury, visceral organ transplant failure, stroke, pulmonary and systemic hypertension, and atherosclerosis (Murad et al., 1978; Lucas et al., 2000; Loscalzo, 2001; Voetsch et al., 2004; Mitrovic et al., 2011).

Here, we first review molecular factors that modulate sGC activity under healthy and diseased conditions. The sGC enzyme is tightly regulated by its oligomeric and conformational state, endogenous and pharmacological ligands, post-translational modification, the cellular redox environment, sub-cellular localization, and protein-protein interactions. We then highlight the role of matricellular protein signaling, in particular TSP1, in inhibiting sGC activity and its potentially important implications for angiogenesis and blood flow.

\section{THE NO-sGC-cGMP PATHWAY IN THE CARDIOVASCULAR SYSTEM}

Physiologic (low dose) NO is formed via two primary pathways. $\mathrm{NO}$ is generated when endothelial nitric oxide synthase (eNOS) is activated by $\mathrm{Ca}^{2+} /$ calmodulin binding in response to external stimuli including laminar blood flow and hormonal cues, such as vascular endothelial growth factor (VEGF) (Zhao et al., 1999). Another source of NO arises from the reduction of dietary nitrates to nitrite and eventually NO. This latter source of NO is eNOS-independent and is likely relevant in conditions of hypoxia (reviewed in Lundberg et al., 2008; Weitzberg and Lundberg, 2013). The half-life of NO under physiological conditions is roughly $0.1 \mathrm{~s}$ (Kelm and Schrader, 1990) and its affinity for sGC is in the picomolar to low nanomolar range (Stone and Marletta, 1996; Tsai et al., 2012a), indicating that sGC is highly responsive to low NO concentrations. NO binding to sGC increases enzyme activity several hundred fold by inducing a transition from a basal to an activated state (Moncada and Higgs, 1993). Downstream of sGC, cGMP interacts with two different classes of effector molecules to achieve vascular smooth muscle relaxation: cGMP-dependent kinase (cGKs) and phosphodiesterases (PDEs) (Lincoln and Cornwell, 1993; Wu et al., 2000). The final cellular concentration of cGMP depends on the rate of production by sGC and the rate of hydrolysis by cGMP PDEs.

\section{SGC IS A MODULAR HETERODIMERIC ENZYME}

Cytoplasmic sGC exists as a heterodimer of an $\alpha$ and a $\beta$ subunit. Heterodimerization is crucial for catalytic activity of sGC since both subunits contribute residues to the active site that is formed at the interface of the catalytic domain (Buechler et al., 
1991). However, homodimers exist in vitro and cell lysates (Zabel et al., 1999) and certain functions have been attributed to a single subunit in vivo (Gao et al., 2013). It has been further proposed that homo- and heterodimerization may regulate activity in vivo and that inactive homodimer pools may regulate the formation of active and activatable heterodimers within the cell (Zabel et al., 1999; Zhou et al., 2008).

Mammals have two different isoforms of each sGC subunit. The $\alpha_{1} \beta_{1}$ sGC heterodimer is the best characterized and is the predominant form in the cardiovascular system (Gupta et al., 1997; Mergia et al., 2003). The regulatory N-terminal domain of the $\beta$ subunit harbors a heme prosthetic group that is the primary NO binding site of the enzyme (Gerzer et al., 1981). The high-resolution three dimensional structure of sGC is unknown but crystal structures of individual domains or domain homologs have been determined for the HNOX domain (Nioche et al., 2004; Pellicena et al., 2004; Ma et al., 2007; Olea et al., 2008; Erbil et al., 2009; Martin et al., 2010; Olea et al., 2010; Weinert et al., 2010, 2011; Winter et al., 2011), the HNOXA domain (Ma et al., 2008; Purohit et al., 2013), the CC domain (Ma et al., 2010), and the GC domain (Rauch et al., 2008; Winger et al., 2008; Allerston et al., 2013; Seeger et al., 2014). Recent studies suggest how these domains assemble in space to form the full-length enzyme. Winger et al., first suggested that $\beta$ HNOX directly binds to and inhibits the cyclase domains (Winger and Marletta, 2005). Later studies supported this hypothesis, and further showed close proximity of the $\beta$ HNOX and cyclase domains (Haase et al., 2010; Underbakke et al., 2013; Busker et al., 2014). Recent studies also demonstrated that $\alpha$ HNOX and $\alpha$ HNOXA maintain the $\beta$ HNOX in an inhibited state that is released upon $\mathrm{NO}$ /activator binding thus leading to cyclase activation (Fritz et al., 2013; Purohit et al., 2014). Complementing this model of auto-inhibition, a comprehensive regulation mechanism was recently proposed whereby the activity of sGC is fine-tuned by distinct domain interactions that either inhibit or promote an optimal conformation of the active center (Seeger et al., 2014). Low-resolution electron microscopy (EM) data on rat sGC confirm most previous observations regarding the domain arrangement of sGC (Campbell et al., 2014). The EM envelope shows two distinct lobes comprising the HNOX and HNOXA domains at the N-terminus and the GC domains at the C-terminus. These two lobes are connected by a parallel CC domain linker. The reconstruction suggests that the full-length enzyme is highly flexible around the HNOXA-CC and CC-GC domain borders and explore a wide range of conformational space. Substrate and/or NO binding to the enzyme do not seem to stabilize specific conformations or restrict the movement observed in the apo enzyme. The lack of observation of distinct conformations that may correspond to the basal and activated state of the enzyme leads to the conclusion that domaindomain interactions as well as small intra-molecular changes account for the transition between the two activity states of sGC (Campbell et al., 2014; Seeger et al., 2014). Despite these significant advances, the exact mechanism by which sGC propagates the $\mathrm{NO}$ activation signal from the regulatory $\mathrm{N}$-terminus to the catalytic C-terminus of the protein remains elusive (reviewed in Derbyshire and Marletta, 2012; Fritz et al., 2013; Underbakke et al., 2013).

\section{SGC ACTIVATION BY NO}

When NO binds to the $\beta$ subunit heme of sGC, a complex is formed in which both $\mathrm{NO}$ and $\beta$-His ${ }^{105}$ axially ligate the $\mathrm{Fe}^{2+}$ atom (Stone et al., 1995; Stone and Marletta, 1996; Zhao et al., 1999; Goodrich et al., 2010). This NO binding event leads to elongation and possibly breakage of the Fe-His ${ }^{105}$ bond and formation of the NO-bound sGC species (Dierks et al., 1997). Subsequent structural rearrangements in the enzyme lead to a 100-200 fold increase in enzyme activity (Wedel et al., 1994; Russwurm and Koesling, 2004; Cary et al., 2005; Pal and Kitagawa, 2010).

The first NO binding event is instantaneous (Stone and Marletta, 1996). Subsequent decay of the NO-sGC-His ${ }^{105}$ complex can form two catalytically distinct species: a high- and a low-activity NO-sGC (Russwurm and Koesling, 2004; Cary et al., 2005; Derbyshire et al., 2008). In conditions of excess NO or stoichiometric NO in the presence of substrate or product, the fully active NO-sGC species is formed (Russwurm and Koesling, 2004; Cary et al., 2005; Tsai et al., 2012a). In conditions of stoichiometric amounts of NO in the absence of substrate or products, a highly active NO-sGC species is formed that then rapidly degrades into a low-activity NO-sGC species (characterized by cGMP formation levels only a few fold above the basal level) (Tsai et al., 2011).

\section{POTENTIAL MECHANISMS OF SGC DESENSITIZATION}

Interestingly, once exposed to NO, sGC decreases its cGMP output during subsequent $\mathrm{NO}$ exposure - a process termed desensitization (Mulsch et al., 1988; Schroder et al., 1988). Three potential mechanisms may be responsible for sGC desensitization: (i) heme oxidation (Schrammel et al., 1996; Zhao et al., 2000), (ii) heme nitrosylation by a second NO molecule (Tsai et al., 2011), or (iii) S-nitrosation of Cys residues in close proximity to the heme pocket (Sayed et al., 2007; Fernhoff et al., 2009; Mayer et al., 2009; Baskaran et al., 2011). The deactivation of sGC-the transition from the activated to the basal/sensitized state-is not as well understood as the process of sGC activation. Whether the dissociation of NO from the enzyme directly leads to deactivation remains controversial: in vitro, deactivation occurs within minutes after NO dissociation (Kharitonov et al., 1997; Brandish et al., 1998); in contrast, in vivo, NO dissociation leads to enzyme deactivation within seconds (Bellamy et al., 2000). sGC stimulators slow down sGC deactivation (Russwurm et al., 2002). Other sGC activity regulators such as nucleotides do not appear to influence the deactivation mechanism (Margulis and Sitaramayya, 2000; Russwurm et al., 2002).

\section{NUCLEOTIDES, SMALL MOLECULES, AND CALCIUM INHIBIT SGC ACTIVITY AND ACTIVATION}

Several small molecules, including heme-oxidizing agents and calcium have been shown to inhibit sGC activity (Figure 1). The nucleotides ATP, UTP, and CTP have been shown to be competitive, allosteric, or mixed-type inhibitors of sGC (Brandwein et al., 1982; Gille et al., 2004; Ruiz-Stewart et al., 2004; Chang et al., 2005). Heme-oxidizing molecules such as ODQ (1H-[1,2,4] oxadiazolo[4,3-a]quinoxalin-1-one), NS2028 (8-bromo-4H-2, 5-dioxa-3, 9b-diaza-cyclopenta[a] 


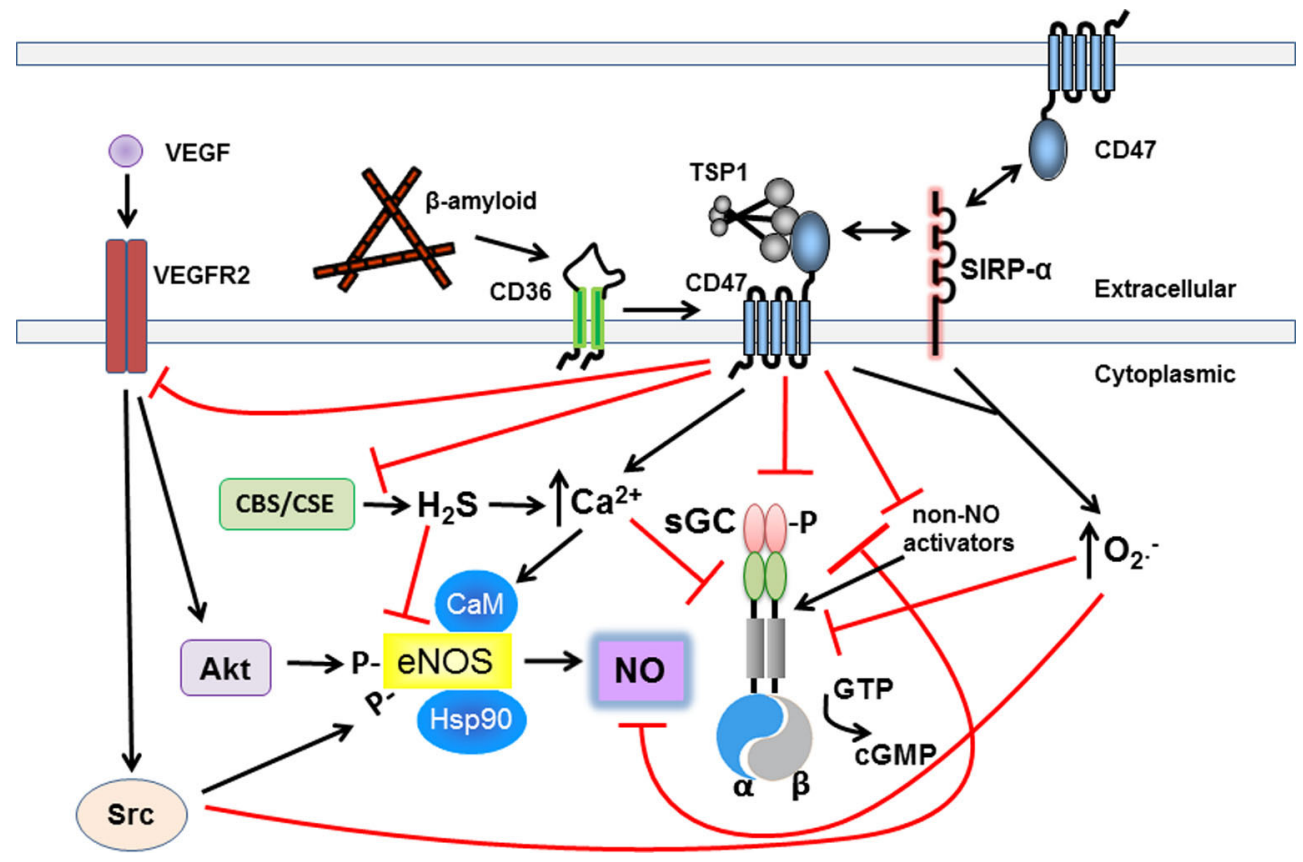

FIGURE 1 | Matricellular TSP1 via CD47 restricts NO-sGC-cGMP signaling. TSP1 inhibits the SGC-cGMP axis via multiple mechanisms to circumvent its beneficial effects. Upstream of sGC-cGMP, TSP1 engages CD47 altering cell calcium flux and VEGF receptor signaling to inhibit eNOS-stimulated NO production. TSP1 via CD36 also inhibits eNOS stimulation in endothelial cells by limiting essential free fatty acid uptake (not pictured). TSP1 through CD47, and SIRP- $\alpha$, stimulates pathologic superoxide production which catabolizes NO. Increased ROS can be expected to alter adversely key protein residues further inhibiting the sGC-cGMP pathway. At the levels of sGC, TSP1 via CD47 directly inhibits sGC and inhibits its sensitivity to NO and non-NO activation. TSP1 can also stimulate increased calcium flux in certain cells which inhibits SGC activation in T cells. TSP1 via CD47 also inhibits synthesis of $\mathrm{H}_{2} \mathrm{~S}$ which in turn regulates SGC. Extracellular $\beta$-amyloid binds to CD36 and cross talk with CD47 inhibits NO and non-NO activation of sGC. Finally, in vascular smooth muscle cells and platelets TSP1 via CD47 inhibits activation of cGMP-dependent protein kinase. naphthalen-1-one), LY8358369, and methylene blue (Gruetter et al., 1981) inhibit sGC activation by oxidizing its heme moiety (Garthwaite et al., 1995). Heme oxidation is detrimental to enzyme activity for two reasons: (1) Ferric heme has a lower affinity to NO than ferrous heme (Schrammel et al., 1996; Zhao et al., 2000; Fritz et al., 2011), thus NO is unable to activate oxidized sGC as effectively, and (2) Oxidized ferric heme readily dissociates from the enzyme, rendering it insensitive to NO (Fritz et al., 2011). Additionally, heme-free sGC is prone to degradation (Stasch et al., 2006), exacerbating the effect of heme oxidation in vivo. The anti-malaria drug artemisinin inhibits NO-stimulated sGC activity with no effect on basal activity (Piatakova and Severina, 2012), although the mechanism of inhibition is unknown. Finally, calcium directly inhibits basal and activated sGC in vivo and in vitro (Parkinson et al., 1999; Serfass et al., 2001; Kazerounian et al., 2002; James et al., 2009).

\section{SGC PHOSPHORYLATION AND DEPHOSPHORYLATION}

Basal and stimulated sGC activity can both be regulated by post-translational modifications including phosphorylation and dephosphorylation. Depending on the identity of the kinase/phosphatase, sGC can be either inhibited or stimulated via the addition/removal of a phosphate group to/from a Ser, Thr, or Tyr residue. Phosphorylation (Murthy, 2004; Zhou et al., 2008) and dephosphorylation (Ferrero et al., 2000) of the cGMP target $\mathrm{PKG}$, and phosphorylation of the protein tyrosine kinase
c-SRC (Meurer et al., 2005; Murthy, 2008) have been shown to be inhibitory (Figure 1). Phosphorylation by protein kinase $\mathrm{C}$ (PKC) (Louis et al., 1993) and protein kinase A (PKA) (Zwiller et al., 1981) have been reported to have sGC activating effects. Phosphorylation by $\mathrm{Ca}^{2+/}$ calmodulin-dependent protein kinase (CaMK) further mediates membrane localization of sGC in cardiomyocytes (Agullo et al., 2005), which may influence the activity state of the enzyme as well.

\section{SGC THIOL OXIDATION}

Human sGC contains 37 Cys residues: 14 in the $\beta$ and 23 in the $\alpha$ subunit. Consequently, S-nitrosation has been postulated to affect both activation (Fernhoff et al., 2009) and desensitization (Sayed et al., 2008). It was hypothesized that full activation of sGC may only be achieved when a second NO molecule (in addition to the first heme-bound NO) S-nitrosates an unidentified Cys residue on the protein surface (Fernhoff et al., 2009). Biochemical, crystallographic, and mutagenesis studies reveal that S-nitrosation causes NO desensitization of the ferric form of sGC (Sayed et al., 2007). sGC can also be inhibited via mixed disulfide formation of naturally occurring compounds such as cystamine and oxidized coenzyme A (Brandwein et al., 1981). Depletion of the cellular reducing equivalents NADPH and glutathione may cause further sGC thiol oxidation and decreases in enzyme activity (Wu et al., 1992; Mingone et al., 2006). Additional evidence reveals that sGC and protein disulfide isomerase (PDI) co-localize in smooth 
muscle cells (Heckler et al., 2013). In vitro data from COS-7 cell lysates suggests that a disulfide bond exchange between PDI and sGC decreases NO-stimulated activity. The exact mechanism and identification of putative Cys residues involved in this process is the subject of current investigation. Combined, these observations corroborate the importance of the redox state of Cys residues in modulating $\mathrm{sGC}$ enzyme activity.

\section{OXIDATIVE STRESS IN CARDIOVASCULAR DISEASES DOWNREGULATES SGC AND ENOS EXPRESSION}

In contrast to the pharmacologic effects of chemical oxidizing agents such as ODQ, the oxidative cellular environment found in many chronic cardiovascular diseases (Cai and Harrison, 2000) also promotes loss of heme in sGC with a subsequent decrease in sGC activity (Wu et al., 1992). These naturally occurring forms of oxidized sGC not only have a lower affinity to NO but are also prone to proteolysis after losing the non-covalentlybound, oxidized heme (Stasch et al., 2006; Fritz et al., 2011). Exacerbating the effect in cardiovascular disease, sGC and eNOS protein expression is down-regulated in ageing cells while the concentration of the reactive oxygen species (ROS) superoxide anion increases, scavenging available NO (Bauersachs et al., 1998). NO and ROS not only regulate sGC activity at the protein level but also influence sGC gene expression at the transcriptional and translational level (Gerassimou et al., 2007). This is relevant in light of new work (discussed below) that describes regulation of NO and ROS by matricellular proteins.

\section{SGC LOCALIZATION MODULATES ENZYMATIC ACTIVITY}

Localization of sGC from the cytosol to the membrane may influence enzyme activity through changes in the redox microenvironment and bioavailability of NO. sGC localizes to the plasma membrane in heart tissue in a calcium-dependent fashion (Zabel et al., 2002). Enzyme that fails to localize to the caveolae is more prone to oxidation and consequent heme loss (Linder et al., 2005; Tsai et al., 2012b). Additionally, sGC is more efficiently activated when associated with the membrane because of higher $\mathrm{NO}$ availability at that locale. In the cytosol of cardiac myocytes, $\mathrm{NO}$ is readily scavenged by myoglobin (Wykes and Garthwaite, 2004). Hence, cellular micro-domains are crucial for sGC function. The protein AGAP1 (ArfGAP protein with a GTPase-like domain, Ankyrin repeats, and a pleckstrin homology domain) may regulate the intracellular distribution of sGC and thus the local delivery of cGMP in mammalian cells (Meurer et al., 2004). The G-protein regulator LGN [Leu-Gly-Asn repeat-enriched protein; also called GPSM2 (G-protein signaling modulator-2) and its homolog AGS3 (activator of G-protein signaling 3)-like] both inhibit sGC activity in cell lysates likely by regulating its cellular localization. Hsp70 and sGC interact in COS-7 cells and colocalization to the plasma membrane has been shown (Balashova et al., 2005). In the central nervous system, the post-synaptic density protein 95 (PSD-95) interacts with the $\alpha 2 \beta 1$ isoform of sGC (Russwurm et al., 2001) and targets sGC to the postsynaptic membrane (Brenman et al., 1996). Additionally, in studies employing co-immunoprecipitation, the $\alpha 1 \beta 1$ sGC enzyme forms a trimeric complex with heat-shock protein 90 (hsp90) and eNOS that localizes to the plasma membrane in aortic smooth muscle cells (Venema et al., 2003). Further confirmation with additional methodologies will be required to verify these results. Recently hsp90 was shown to directly interact with heme-depleted sGC and aid heme incorporation using its inherent ATPase chaperone activity (Ghosh and Stuehr, 2012). It is important to emphasize that most of sGC's interactions with other proteins have only been shown in vitro or in cell culture using immunoprecipitation and yeast-to-hybrid assays, and lack confirmation in vivo. Further research must provide a physiological context for these observed interactions.

\section{PHARMACOLOGICAL ACTIVATION OF SGC IN CARDIOVASCULAR DISEASES: NO DONORS, STIMULATORS, AND ACTIVATORS}

Therapeutic agents that target sGC can be divided into three categories: NO donors, sGC stimulators, and sGC activators. Stimulators of sGC synergize and sensitize sGC for activation with NO; activators on the other hand are NO- and hemeindependent. NO donor treatment is associated with side effects that include non-specific interactions of NO with other cellular proteins and tolerance development. Thus, there is a need for activators as well as stimulators to directly target sGC and increase cellular cGMP levels in disease states. A prominent sGC stimulator is BAY63-2521 (Riociguat). Riociguat raises the potency of sGC activation by NO and has been approved for the treatment of pulmonary arterial hypertension (Ghofrani et al., 2013). The mode of binding of Riociguat, and other stimulators, to sGC is unknown (Schermuly et al., 2011). In contrast, BAY58-2667 (Cinaciguat) - an sGC activator-works in a NO- and hemeindependent manner (Chester et al., 2011; Erdmann et al., 2013) by replacing the heme moiety (Martin et al., 2010). The development of hypotension in patients with acute decompensated heart failure of the Phase IIb clinical trial likely rendered this compound unsuitable for widespread application in this condition (Erdmann et al., 2013). Other heme-replacing activators are BAY 60-2770 and HMR1766 (Ataciguat) (Mendes-Silverio et al., 2012; Kumar et al., 2013). While the mode of binding of sGC activators has been structurally characterized, the binding sites of sGC stimulators remain unknown. Recent evidence, however, suggests that the experimental stimulator YC-1 binds to the $\beta$ HNOX and/or $\beta$ HNOXA domains (Purohit et al., 2014).

\section{MATRICELLULAR PROTEINS AND EMERGING sGC REGULATORY MECHANISMS}

Matricellular proteins are so named because they bind to both structural proteins, such as collagen within the extracellular matrix, and to cells via cell membrane receptors (Lawler and Lawler, 2012). In this capacity they modulate both cellular and matrix processes (Bornstein, 2009). Matricellular proteins themselves do not have known structural function, but they can alter the production and maintenance of matrix directly and through effects upon cells within the matrix (Mosher and Adams, 2012). The role of matricellular proteins in regulating cardiovascular events has been primarily defined in terms of angiogenesis-the process of new blood vessel formation. Angiogenesis (Isenberg et al., 2005a) is required for the healing response that is initiated 
by wounding and requires days to weeks complete (Miller et al., 2009). Consequently, the kinetics of matricellular signaling, as it relates to the vasculature and blood flow, have been conceptualized as subacute and chronic. Matricellular proteins have a newfound role in regulating acute cardiovascular events including vessel contractility and blood flow. These insights have stemmed from the recently discovered ability of a prototypical member of this class of proteins to rapidly and redundantly limit the canonical NO signaling pathway in vitro and in vivo (Isenberg et al., 2009b) (Figure 1).

\section{TSP1 IS A PROTOTYPICAL MATRICELLULAR PROTEIN}

One of the first identified matricellular proteins that has served as a prototypical example of this class of molecules is thrombospondin-1 (TSP1) (Baenziger et al., 1971; Lawler et al., 1978). TSP1 is the most widely studied member of the thrombospondin family (Bornstein et al., 1991). Five thrombospondins are found in vertebrates (Adams and Lawler, 2011), and of these TSP1 and thrombospondin-2 (TSP2) function as regulatory matricellular proteins in the vascular system. TSP1 is known to interact with at least nine separate cell receptors. TSP1 contains a linear arrangement of functional domains and assembles into a trimeric complex via disulfide bonds near the $\mathrm{N}$-terminus. The $\mathrm{N}$-terminal domain, the central type 1 repeats and C-terminal domain of TSP1 interact with distinct receptors on vascular cells to modulate cell viability (Guo et al., 1997), growth (Taraboletti et al., 1990; Bagavandoss et al., 1993), motility (Vogel et al., 1993; Calzada et al., 2003), contractility (Isenberg et al., 2006b), and gene expression (Kaur et al., 2013). TSP1, directly and indirectly, promotes platelet activation and thrombosis (Bonnefoy et al., 2006; Isenberg et al., 2008e). Given that differential expression of the several TSP1 receptors can change the outcome of its interactions with vascular cells, it is not surprising that contradictory activities have been ascribed to this protein. Early reports linked TSP1 to decreased tumor growth through inhibitory activity on endothelial cell migration and proliferation, with subsequent decreased angiogenesis (Good et al., 1990). Conversely, in arterial smooth muscle cells (Majack et al., 1986) and in retinal pericytes [a smooth muscle like cell associated with capillaries (Scheef et al., 2009)] TSP1 has the opposite effect and promotes proliferation and cell hypertrophy (Wang and Frazier, 1998). Recently, clarification of several contradictory activities ascribed to TSP1 has come from the finding of an intersection between NO signaling and this matricellular protein. These findings have also provided increased understanding of sub-acute and chronic signaling events attributed to TSP1.

\section{REGULATION OF SGC AND cGMP BY THROMBOSPONDINS}

TSP1 limits tumor growth and tumor-associated vascularization (Isenberg et al., 2009b). This well-characterized anti-angiogenic activity was localized to the type 1 repeat domain of TSP1 (Tolsma et al., 1993; Iruela-Arispe et al., 1999), which mediates interaction with the cell surface receptor CD36 (Dawson et al., 1997). TSP1 inhibited growth factor-stimulated corneal angiogenesis in wild type $\left(\mathrm{CD}^{+/+}\right)$mice but not in $\mathrm{CD}^{+/-}$mice (Jimenez et al., 2001). Conversely, in wild type mice treated with a CD36 antibody, TSP1 binding and activation of the receptor was blocked, which increased inflammatory-stimulated corneal angiogenesis (Mwaikambo et al., 2006). More recently, exogenous TSP1, the recombinant type 1 repeat protein domain of TSP1, and a CD36-targeting peptide (based on the proposed CD36 binding site of TSP1) all limited NO-stimulated effects including proliferation and migration of vascular endothelial cells (Isenberg et al., 2005b). TSP1 also rapidly limited NO-mediated activation of sGC to suppress cGMP production. Exogenous TSP1 inhibited sGC sensitivity to NO within 10 min of treatment. Of note, TSP1-mediated inhibition of sGC and downstream suppression of cGMP production is not secondary to alterations in PDE activity. These data indicate that TSP1-CD36 signaling is sufficient to limit NO-sGC signaling in endothelial cells. Arterial smooth muscle cells and platelets also express CD36 in the cell membrane. Treating cells for $10 \mathrm{~min}$ with exogenous TSP1 inhibited NO signaling via CD36 as well (Isenberg et al., 2006b, 2008e). The data further suggest that (1) this inhibitory effect occurs in a short period of time, and (2) this is an inhibitory pathway common to all vascular cells. Dose response experiments indicate that primary vascular cells are extremely sensitive to TSP1 with 2.2-22 pmol/L concentrations of TSP1 completely inhibiting NO activation of sGC. Comparison with published dosages in growth factor studies suggests TSP1 inhibition of NO may be a more sensitive signal and may dominate in a given micro-environment in vivo.

In a wound healing assay, skeletal muscle angiogenesis stimulated by exogenous $\mathrm{NO}$ was potently inhibited by the addition of exogenous TSP1 (Isenberg et al., 2005b). Surprisingly, CD36-/muscle explants and endothelial cells remained sensitive to TSP1mediated inhibition of sGC-cGMP signaling (Isenberg et al., 2006a). The finding that CD36-/- cells were susceptible to TSP1mediated inhibition of NO effects suggested that an alternative cell receptor for TSP1 may play a more important role in this process. TSP1 was demonstrated to functionally interact with the widely expressed cell receptor CD47 (McDonald et al., 2003). CD47 was originally ascribed roles in mediating cell adhesion, platelet activation, macrophage recognition of self (Oldenborg et al., 2000) and integrin signaling (Brown and Frazier, 2001). Our team confirmed that TSP1 binds CD47 with very high affinity (Isenberg et al., 2009a). In contrast to results in CD36-/- tissues, NO-stimulated skeletal muscle angiogenesis in $\mathrm{CD} 47^{-/-}$explants is resistant to TSP1 inhibition (Isenberg et al., 2006a). At the level of sGC, CD47-/- endothelial cells have higher basal and NOstimulated cGMP production than wild type cells. Conversely, TSP1-mediated inhibition of basal sGC and NO-mediated activation is absent in $\mathrm{CD} 47^{-/-}$endothelial and vascular smooth muscle cells. Importantly, TSP1 inhibition of sGC activation via CD36 requires the presence of CD47 (Isenberg et al., 2006a). TSP1 also inhibits uptake of free fatty acids via CD36, and this, in turn, limits myristylation of Src-family kinases and downstream activation of eNOS (Isenberg et al., 2007c). Thus, concentrations of TSP1 or TSP1 mimetic drugs such as ABT-510 sufficient to inhibit the fatty acid translocase activity of CD36 can inhibit sGC activation by limiting eNOS activation and subsequent production of the physiological sGC ligand NO (Isenberg et al., 2008f). 
At higher concentrations the thrombospondin family members TSP1 and TSP4 can also engage CD47 to inhibit NO-mediated sGC activation (Isenberg et al., 2009a). However, physiological regulation of sGC activity and tissue perfusion was not perturbed in TSP2 $2^{-/-}$cells and null mice subjected to ischemic injury. Nonetheless, in certain pathological situations alternative thrombospondins, acting through CD47, may inhibit the NO-sGC-cGMP pathway. As tissue- and time-specific expression of these proteins has been reported, this finding may be of clinical importance. TSP1, and a TSP1-derived recombinant domain containing the CD47 targeting portion of the protein termed E123CaG1 both inhibit NO-mediated sGC activity by as much as $>60 \%$, at nanomolar concentrations (Ramanathan et al., 2011). Studies show that under ischemic challenge soft tissue blood flow is lost in $\mathrm{CD}^{-/-}$animals, whereas it is preserved in $\mathrm{CD} 47^{-/-}$animals (Isenberg et al., 2008c), establishing CD47 as the necessary receptor for TSP1 signaling to regulate $\mathrm{sGC}$.

Calcium has been shown to directly inhibit sGC basal function and limit ligand activation of the enzyme in vivo and in vitro (Parkinson et al., 1999; James et al., 2009). In this context, sGC activation by both stimulators and activators is inhibited by TSP1 (Isenberg et al., 2008a; Miller et al., 2010a) (Figure 1). Human endothelial cells treated with TSP1 $(2.2 \mathrm{nmol} / \mathrm{L})$ followed by the calcium ionophore ionomycin demonstrated a decrease in the expected sustained $\mathrm{Ca}^{2+}$ release phase. In freshly harvested arteries, en face analysis found that TSP1 inhibited ionophoremediated calcium wave propagation on the endothelium monolayer (Bauer et al., 2010). This is in contrast to TSP1 activity in Jurkat $\mathrm{T}$ cells, where both the whole protein and a recombinant C-terminal domain(E123CaG1) that we previously demonstrated interacts selectively with CD47 (Isenberg et al., 2009a), increased cytosolic $\mathrm{Ca}^{2+}$ and inhibited sGC (Ramanathan et al., 2011). Upon the interaction of TSP1 or E123CaG1 with the cell membrane, intracellular $\mathrm{Ca}^{2+}$ concentrations increased to $300 \mathrm{nM}$, which in turn activated $\mathrm{Ca}^{2+/}$ calmodulin-dependent kinase(s) that putatively inactivated/inhibited sGC through phosphorylation at a yet to be determined residue (Agullo et al., 2005). The inhibitory modification(s) of sGC induced by TSP1-CD47 signaling is stable to disruption of the cell membrane following treatment with E123CaG1 (Ramanathan et al., 2011). TSP1 treatment also increases cytosolic $\mathrm{Ca}^{2+}$ in several non-vascular cell types, specifically mast cells and fibroblasts, though the effect this has on NO-sGC-cGMP signaling in these cells is not known (Tsao and Mousa, 1995; Sick et al., 2009). This recent work provides mechanistic insight for a CD47 antibody inhibiting fibronectin, but not histamine-induced $\mathrm{Ca}^{2+}$ entry in endothelial cells (Schwartz et al., 1993). Together these data suggest that activated CD47 regulates a non-classical calcium channel in vascular cells.

To date, cell culture experiments in wild type and CD47-/endothelial and vascular smooth muscle cells and platelets have provided genetic confirmation that TSP1, via CD47, inhibits both basal and NO-stimulated sGC activation (Isenberg et al., 2006a). This process extends to a wide range of mammalian cells as confirmed using vascular cells from mice (Isenberg et al., 2006a), rats (Maxhimer et al., 2009; Yao et al.,
2011), pigs (Isenberg et al., 2008d), cows (Bauer et al., 2010; Kaur et al., 2010) and human vascular cells (Isenberg et al., 2005b).

\section{TSP1 INHIBITS PHARMACOLOGIC ACTIVATION OF sGC}

Unwanted side effects to NO donor drugs (Rindone and Sloane, 1992) and tolerance following chronic drug exposure (Munzel et al., 2005) have led to efforts to develop sGC stimulators and activators that enhance NO sensitivity and do not require $\mathrm{NO}$ at all for enzyme activation. Several of these agents are currently in clinical trials for treatment of cardiovascular diseases (Evgenov et al., 2006; Stasch et al., 2011; Cannon and Pepke-Zaba, 2014). Not surprisingly, TSP1-CD47 inhibition of NO-mediated activation of sGC raised the question of whether TSP1 also inhibited sGC in the presence of sensitizers and activators. In platelets, which also express CD47, a low concentration of TSP1 $(2.2 \mathrm{nmol} / \mathrm{L})$ inhibited the disaggregation stimulated by several small molecule activators and stimulators of sGC including YC1, BAY 41-2272 and meso-porphyrin IX (Miller et al., 2010a). The same concentration of TSP1 inhibited vascular smooth muscle cell relaxation stimulated by these compounds. TSP1 limited the expected increase in cGMP induced by YC1, BAY 41-2272 and PPIX, confirming that sGC was the direct target of this effect. As these agents synergize with both $\mathrm{NO}$ and $\mathrm{CO}$ to increase sGC activity, these data suggest TSP1 may limit biogas signaling from several sources (see below). Interestingly, the TSP1-derived CD47 activating domain E123CaG1 also inhibited YC-1- and BAY 41-2272-mediated stimulation of sGC. This inhibition could only be reversed by adding back exogenous NO (Ramanathan et al., 2011). This finding may be of clinical relevance, as NO-independent stimulators and activators of sGC are being developed for use in diseases, including pulmonary hypertension (Mittendorf et al., 2009), in which NO signaling is reduced or absent (Rabinovitch, 2007; Stasch and Evgenov, 2013) and, as we have shown, TSP1-CD47 signaling concurrently upregulated (Bauer et al., 2012).

\section{ALTERNATIVE LIGAND ACTIVATION OF THE CD36-CD47 COMPLEX BY $\beta$-AMYLOID INHIBITS NO-AND CHEMICAL-MEDIATED SGC STIMULATION}

The secreted protein $\beta$-amyloid has been hypothesized to interact with CD36 and CD47 (Bamberger et al., 2003; Wilkinson et al., 2006) (Figure 1). This finding suggested that $\beta$-amyloid may act via CD36 and CD47 to inhibit vascular cell sGC-cGMP signaling. Interestingly, $\beta$-amyloid protein, and peptides derived from the same, limited essential fatty acid uptake via CD36 (a classic fatty acid translocase). $\beta$-amyloid peptides inhibited sGC activation by a primary NO donor and stimulation by BAY 41-2272 in several cell types including bovine endothelial cells, porcine vascular smooth muscle cells and human $\mathrm{T}$ cells (Miller et al., 2010b). The inhibitory effect was greatest in human $\mathrm{T}$ cells and characterized by an $\mathrm{IC}_{50}$ in the nanomolar range. Gene silencing of CD36 attenuated, while gene silencing of CD47 abolished, $\beta$-amyloid-mediated inhibition of sGC. Endogenous TSP1 did not further regulate this response. Thus $\beta$-amyloid functions as an alternative activator of the CD36-CD47 complex to potently inhibit sGC-cGMP signaling. 


\section{TSP1 INHIBITS OTHER BIOGAS LIGANDS AND ACTIVATORS OF sGC}

TSP1 signaling through CD47 may also modulate cGMP signaling indirectly via its inhibition of hydrogen sulfide $\left(\mathrm{H}_{2} \mathrm{~S}\right)$ signaling (Figure 1). $\mathrm{H}_{2} \mathrm{~S}$ can regulate NO-sGC-cGMP signaling through regulation of NO synthesis and metabolism (Whiteman and Moore, 2009). TSP1 acting through CD47 in T cells limits the activation-dependent induction of the $\mathrm{H}_{2} \mathrm{~S}$ biosynthetic enzymes cystathionine $\beta$-synthase (CBS) and cystathionine $\gamma$-lyase (CSE) (Miller et al., 2013). TSP1 also inhibits the activity of exogenous $\mathrm{H}_{2} \mathrm{~S}$ to activate $\mathrm{T}$ cells. Exogenous TSP1 inhibited $\mathrm{H}_{2} \mathrm{~S}$ responses in wild type and TSP1 ${ }^{-1-} \mathrm{T}$ cells but enhanced the same responses in $\mathrm{CD} 47^{-/-} \mathrm{T}$ cells. Engaging $\mathrm{CD} 47$ using a CD47-binding peptide derived from TSP1 similarly inhibited signaling. TSP1 signaling via CD47 thereby blocks the autocrine function of $\mathrm{H}_{2} \mathrm{~S}$ to increase $\mathrm{T}$ cell activation (Miller et al., 2012).

Several mechanisms have been proposed through which $\mathrm{H}_{2} \mathrm{~S}$ can regulate NO-sGC-cGMP signaling including regulation of NO synthesis and metabolism (reviewed in Whiteman and Moore, 2009). In pancreatic acini, $\mathrm{H}_{2} \mathrm{~S}$ was found to increase $\mathrm{Ca}^{2+}$ levels (Moustafa and Habara, 2014). The elevated calcium levels were shown to increase NO synthesis, consistent with the known calcium regulation of eNOS. However as noted above, altered calcium levels can also directly modulate sGC activity. In mice lacking the $\mathrm{H}_{2} \mathrm{~S}$ biosynthetic enzyme CSE, the reduced $\mathrm{H}_{2} \mathrm{~S}$ levels were associated with increased left ventricular hypertrophy after transverse aortic constriction (Kondo et al., 2013). $\mathrm{H}_{2} \mathrm{~S}$ signaling was shown to stimulate VEGF production and Akt-dependent eNOS phosphorylation in this model of pressure overload heart failure, which led to increased cGMP synthesis. Finally, $\mathrm{H}_{2} \mathrm{~S}$ induced increased expression of eNOS and iNOS in the vessel walls of treated mice. The anti-thrombotic activity of $\mathrm{H}_{2} \mathrm{~S}$ in these mice was partially reversed by administration of the general nitric oxide synthase inhibitor $\mathrm{L}-\mathrm{N}_{G}$-nitroarginine methyl ester (L-NAME) (Kram et al., 2013). A similar induction of eNOS expression by $\mathrm{H}_{2} \mathrm{~S}$ was reported in rat corpus cavernosum (Meng et al., 2013).

\section{TSP1 CONTROLS UPSTREAM AND DOWNSTREAM REGULATION OF THE SGC-cGMP AXIS}

Loss of sGC-cGMP signaling in endothelial cells could be caused by direct inhibition of sGC and/or proximal inhibition of NO production at the level of the eNOS. Wild type endothelial cells that express both TSP 1 and CD47 display decreased cGMP production compared to $\mathrm{CD} 47^{-/-}$cells after stimulation with the eNOS agonist acetylcholine, while treating human endothelial cells with TSP1 inhibited eNOS-mediated production of NO (Bauer et al., 2010). This in vitro effect is confirmed in the whole animal as phosphorylation of the key activity-associated eNOS residue serine 1117 is increased in vascular tissues from TSP1 $1^{-/-}$mice compared to wild type. In endothelial cells this is mediated by CD47-dependent inhibition of VEGFR2 phosphorylation (Kaur et al., 2010) (Figure 1), which in turn activates Akt to phosphorylate eNOS. TSP1/CD47 signaling also inhibits Src activation, which as mentioned above can inhibit sGC via phosphorylation. Further redundancy in the TSP1-CD47 axis was found in studies of the downstream cGMP-activated kinase
(PKG). Phosphorylation of this enzyme can be stimulated in a sGC-independent fashion with the cell permeable analogue 8-bromo-cGMP, and TSP1 inhibits this process (Isenberg et al., 2007a, 2008e). Thus TSP1 redundantly suppresses sGC-cGMP signaling by limiting the upstream production of the sGC ligand NO and by limiting the downstream activation of PKG by cGMP. This later effect is particularly important as it suggests that therapeutic strategies based on NO pro-drugs such as nitrite and NO-independent stimulators of sGC, though relieving inhibition at the level of sGC, cannot overcome upstream and downstream pathway inhibition. Therapeutically these findings imply that the combinatorial approach of NO-independent stimulation of sGC and a CD47 signaling blocker may be the most efficient manner to enhance NO-sGC-cGMP-PKG signaling under the chronic conditions of cardiovascular disease.

\section{MATRICELLULAR PROTEIN TSP1 DIRECTLY STIMULATES ROS PRODUCTION TO FURTHER INHIBIT SGC-cGMP SIGNALING}

Cardiovascular disease is characterized by overproduction of pathologic of ROS including superoxide $\left(\mathrm{O}_{2}^{--}\right)$and hydrogen peroxide $\left(\mathrm{H}_{2} \mathrm{O}_{2}\right)$ that in turn modify proteins and adversely alter their function (Chen and Keaney, 2012). Conversely, inhibitors of the enzymatic sources of this pathologic ROS are under development for possible therapeutic advantage (Cifuentes and Pagano, 2006). ROS is well known to limit physiologic NO-sGC-cGMP signaling (see above). Hydrogen peroxide induces specific tyrosine phosphorylation of the $\beta 1$ but not of the $\alpha 1$ subunit of sGC and this may alter enzyme activity (Meurer et al., 2005). ROS can also adversely impact gene function. Treating VSMC with $\mathrm{H}_{2} \mathrm{O}_{2}$ significantly decreased protein levels of the $\alpha$ and $\beta$ subunits of sGC and inhibited SNP-stimulated cGMP formation (Gerassimou et al., 2007). ROS further limits physiologic NO-sGC-cGMP signaling by reacting with NO (Figure 1). In endothelial cells introduction of intracellular- or extracellulargenerated $\mathrm{O}_{2}^{--}$during $\mathrm{NO}$ generation resulted in a concomitant increase in oxidative intermediates with a decrease in steady-state NO concentrations (Thomas et al., 2006). Finally, a number of mechanisms exist that serve to buffer and degrade pathologic ROS. Loss of these ROS suppressing enzymatic systems is noted in cardiovascular disease and is associated with increased sGC S-nitrosylation and decreased activity (Choi et al., 2011).

Recently TSP1 has been linked to cardiovascular disease in people. Elevated plasma TSP1 levels are correlated with vasoocclusive crises (Novelli et al., 2012) and peripheral vascular disease (Smadja et al., 2011); tissue TSP1 protein and mRNA levels are overexpressed in the leg muscles of patients with ischemic peripheral vascular disease (Favier et al., 2005), and single nucleotide polymorphisms of TSP1 and TSP4 are associated with higher rates of early myocardial infarction (Narizhneva et al., 2004; Stenina et al., 2005). Given the known roles ROS plays in cardiovascular disease, this suggested that TSP1 may directly participate in ROS production. Hypoxic challenge of human pulmonary arterial endothelial cells increases TSP 1 and $\mathrm{O}_{2}^{--}$production while treatment with a CD47 antagonist antibody suppresses this effect (Bauer et al., 2012). Ligation of B-cell CD47 induces mitochondrial dysfunction and ROS production, likely as part of a cell 
death process (Mateo et al., 2002). Treatment of vascular smooth muscle cells with a low concentration of TSP1 $(2.2 \mathrm{nmol} / \mathrm{L})$ increases $\mathrm{O}_{2}^{--}$production within $1 \mathrm{~h}$ (Csanyi et al., 2012). In endothelial-denuded arterial rings TSP1 treatment increased CM radical formation as measured with electron paramagnetic resonance. Studies employing pharmacologic inhibitors of enzymatic ROS, siRNA knock down and endothelial free arterial rings from the respective null mice all indicate the source of this $\mathrm{O}_{2}^{-}$is likely the NADPH oxidase 1 (Nox1). TSP1 is a more potent stimulator of ROS compared to the classic activators phorbol myristate acetate and angiotensin II. The CD47 targeting peptide 7N3 that contains the Val-Val-Met sequence also increased VSMC $\mathrm{O}_{2}^{--}$production (Csanyi et al., 2012). Conversely, treating VSMC with a morpholino oligonucleotide to suppress CD47 protein expression (Isenberg et al., 2008d) or an antagonist antibody to block TSP1 binding to CD47, ablated TSP1-mediated $\mathrm{O}_{2}^{--}$production (Csanyi et al., 2012). Thus TSP-CD47 stimulates Nox-derived $\mathrm{O}_{2}^{-}$ production in vascular smooth muscle cells.

TSP1 is currently the only identified soluble ligand of CD47. However, CD47 can be ligated by the cell membrane protein SIRP- $\alpha$ (Vernon-Wilson et al., 2000). In VSMC, SIRP $\alpha$ has been linked to insulin like growth factor-stimulated ROS production (Xi et al., 2013). New studies in VSMC found that TSP1-mediated $\mathrm{O}_{2}^{--}$production was abrogated in cells treated with a SIRP $\alpha$ morpholino oligonucleotide or a SIRP- $\alpha$ blocking antibody (Yao et al., 2014). Likewise, in renal tubular epithelial cells (rTEC), that we have shown expresses CD47 (Rogers et al., 2012), TSP1 (2.2 nmol/L) treatment increased $\mathrm{O}_{2}^{--}$production which was blocked by treatment with a $\operatorname{SIRP} \alpha$ oligonucleotide morpholino and a SIRP- $\alpha$ antagonist antibody (Yao et al., 2014). Together these data show that soluble TSP1 can potently stimulate pathologic $\mathrm{O}_{2}^{--}$production in vascular and epithelial cells and that this was mediated by interactions with both receptors CD47 and SIRP- $\alpha$. It is likely that the TSP1$\operatorname{SIRP} \alpha$ interaction does not extend to other secreted proteins such as $\beta$-amyloid as the fibrillar form of this protein did not inhibit CD47 binding to a SIRP- $\alpha$-Fc fusion protein (Miller et al., 2010b).

\section{TSP1-CD47 REGULATION OF SGC-cGMP SIGNALING HAS EFFECTS ON BLOOD FLOW}

An immediate effect of sGC activation in arterial smooth muscle cells is uncoupling of actin-myosin interaction and relaxation of the cellular contractile response. This process is central to promotion of blood flow through the vasculature. TSP1 treatment blocks NO- and sodium nitroprusside (SNP)-mediated activation of sGC and subsequent dephosphorylation of myosin light chain 2 (the kinase responsible for vasoconstriction) while increasing immuno-reactive F-actin in cultured VSMC (Isenberg et al., 2007a). In vitro studies of VSMC contraction in collagen matrix demonstrated that TSP1 inhibits both NO- and SNP-stimulated relaxation (Isenberg et al., 2007a). In arterial ring myography bioassays, TSP1 (at $0.22 \mathrm{nmol} / \mathrm{L}$ ) and the CD47-targeting domain E123CaG1 (at $2.2 \mathrm{nmol} / \mathrm{L}$ ) inhibit endothelial-dependent vasodilation (Bauer et al., 2010). CD47 ${ }^{-/-}$arterial rings are immune to TSP1-mediated inhibition of vasodilation while exogenous TSP1 continues to inhibit Ach-mediated vasodilation in TSP1-/- arterial rings (Bauer et al., 2010). In soft tissues and visceral organs TSP1 inhibits blood flow following ischemia reperfusion injury (IRI) (Isenberg et al., 2008b; Csanyi et al., 2012) while TSP1-/- (Isenberg et al., 2007a, 2008c) and CD47 ${ }^{-/-}$ animals (Rogers et al., 2012) display enhanced blood flow following ischemia and IRI. Both eNOS and sGC subunit protein expression levels were comparable in vessels from wild type, TSP $1^{-/-}$and $\mathrm{CD}^{-1} 7^{-/}$mice (Bauer et al., 2010) indicating these functional responses are secondary to the acute inhibitory activity of TSP1, via CD47, on the canonical NO-sGC-cGMP pathway.

Based on the above and other work these functional responses may also be, in part, secondary to alternative mechanisms. In VSMC, TSP1 inhibits cAMP-mediated suppression of F-actin organization and inhibits forskolin-stimulated vasodilation of endothelial-free arterial rings (Yao et al., 2011). Alternatively, results in cell cultures suggest that TSP1, via CD47 and/or SIRP- $\alpha$, could control blood vessel dilation and blood flow through stimulating pathologic ROS. In endothelial-free arterial rings gene knock done of Nox1 abrogated TSP1-mediated inhibition of SNPstimulated vasodilation (Csanyi et al., 2012). Likewise treatment of arterial rings with the ROS scavenger Tempol corrected TSP1mediated inhibition of vasodilation (Yao et al., 2014). In animals, an intravenous TSP1 bolus impaired restoration of blood flow following short term $(<1 \mathrm{~h})$ ischemia and this was ameliorated by gene silencing of Nox1 or treatment with a CD47 antagonist antibody (Csanyi et al., 2012). Finally, in animals a SIRP- $\alpha$ antagonist antibody, that blocked TSP1-mediated $\mathrm{O}_{2}^{-}$production, enhanced blood flow restoration following $20 \mathrm{~min}$ of renal ischemia (Yao et al., 2014).

Null vascular cells display enhanced sGC-cGMP signaling. Employing telemetry monitoring of central blood pressure, TSP $1^{-/}$and $\mathrm{CD} 47^{-/-}$mice were found to have a widened pulse pressure (Isenberg et al., 2009c), while CD47-/- mice were significantly hypotensive at rest. Similarly, $\mathrm{TSP} 1^{-/-}$and $\mathrm{CD} 47^{-/-}$ animals undergo greater flux in mean arterial blood pressure following an exogenous $\mathrm{NO}$ challenge compared to wild type (Isenberg et al., 2009c). It is not clear if variation in autonomic nervous system function plays a role in any of these findings as $\mathrm{TSP} 1^{-/-}$and $\mathrm{CD} 47^{-/-}$mice show greater sensitivity to postganglionic blockade with a greater drop in MAP compared to wild type animals (Isenberg et al., 2009c). In the peripheral microcirculation thermal and NO-stimulated flux in cutaneous blood flow is also greater in TSP1 $1^{-/-}$and $\mathrm{CD} 47^{-/-}$mice (Rogers et al., 2013).

Under the stress of chronic hypoxia $\left(10 \% \mathrm{~F}_{i} \mathrm{O}_{2}\right.$ for 3 weeks) TSP $1^{-/-}$mice maintained a more normal cardiovascular profile compared to wild type animals with less change in right ventricular systolic pressure, less right ventricular hypertrophy and less pulmonary vascular smooth muscle cell hyperplasia. This observation was further associated with less pulmonary ROS production (Bauer et al., 2012). TSP1 $1^{-/-}$and CD47 ${ }^{-/-}$mice show improved blood flow and less tissue injury in the hind limb compared to wild type following femoral artery ligation and this benefit in tissue perfusion persists with ageing (Isenberg et al., 2007b). However, wild type and TSP2 $2^{-/-}$mice display comparable amounts of tissue loss in ischemic soft tissue flaps and 
comparable diminution in hind limb blood flow after femoral artery ligation (Isenberg et al., 2009a). A lack of a tissue survival and blood flow advantage in TSP2 $2^{-/-}$mice is consistent with vascular cell culture experiments where the recombinant TSP2 domain inhibited NO-mediated sGC activation modestly (Isenberg et al., 2009a). This is in contrast to results in TSP1TSP2 ${ }^{-/}$mice that show enhanced revascularization following femoral artery ligation compared to wild type animals (Kopp et al., 2006; MacLauchlan et al., 2011).

\section{TSP1-CD47 REGULATION OF SGC-cGMP SIGNALING HAS THERAPEUTIC IMPLICATIONS}

TSP1 accounts for approximately 50\% of the preformed protein within platelet alpha granules. TSP1 antibodies have shown some effect in tissue models of ischemia (Isenberg et al., 2007d, 2008d). However, it is theoretically more efficient to target CD47. In a human cell line a CD47 antagonist antibody blocks TSP1mediated inhibition of sGC. Treating full thickness skin grafts with a CD47 antagonist antibody increased graft healing rates in an animal model (Isenberg et al., 2008c). Antisense suppression of CD47 increased sGC-cGMP signaling in VSMC and ischemic tissue survival. In ApoE null mice that demonstrate an accelerated vasculopathy, blocking CD47 expression with morpholino oligonucleotide enhanced ischemic soft tissue survival (Isenberg et al., 2007b). In a severe tissue ischemia model, treating animals with a CD47 antagonist antibody in combination with an NO pro-drug provided additive benefits increasing tissue survival by $100 \%$ compared to treatment with the NO pro-drug alone (Isenberg et al., 2009d). This later result is clinically relevant as nitrite is being developed for use in humans (see NIH clinical trials NCT01409122 and NCT01715883 among others). Likewise, interrupting matricellular activation of CD47 enhances liver (Isenberg et al., 2008b) and kidney survival (Rogers et al., 2012) following IRI and ablates pulmonary arterial hypertension in rodents (Bauer et al., 2012). In 5th order pulmonary arteries from the lungs of a patient undergoing transplant for end-stage pulmonary arterial hypertension the TSP1-CD47 axis was induced while NO-dependent and independent vasodilation was almost abolished (Rogers et al., 2013; Published online Feb 3, 2014), confirming in human disease activation of the TSP1-CD47 inhibitory axis is concurrent with loss on NOsGC-cGMP signaling. Taken together basic and clinical studies suggest that a more comprehensive way to treat chronic cardiovascular disease would be to combine sGC activation with disruption of the TSP1-CD47 pathway as a novel therapeutic strategy.

\section{FUNDING}

This work was supported by NIH grants R01HL-108954 and 1R01HL112914-01A1 and American Heart Association grants 11BGIA7210001 (Jeffrey S. Isenberg) 10SDG2600345 (Elsa D. Garcin), 13PRE17000045 (Franziska Seeger) and 13POST14520003 (Natasha M. Rogers) and by the Intramural Research Program of the NIH/NCI (David D. Roberts). This work was further supported by the Institute for Transfusion Medicine, the Hemophilia Center of Western Pennsylvania and the Vascular Medicine Institute (Jeffrey S. Isenberg).

\section{REFERENCES}

Adams, J. C., and Lawler, J. (2011). The thrombospondins. Cold Spring Harb. Perspect. Biol. 3:a009712. doi: 10.1101/cshperspect.a009712

Agullo, L., Garcia-Dorado, D., Escalona, N., Ruiz-Meana, M., Mirabet, M., Inserte, J., et al. (2005). Membrane association of nitric oxidesensitive guanylyl cyclase in cardiomyocytes. Cardiovasc. Res. 68, 65-74. doi: 10.1016/j.cardiores.2005.05.021

Allerston, C. K., von Delft, F., and Gileadi, O. (2013). Crystal structures of the catalytic domain of human soluble guanylate cyclase. PLOS ONE 8:e57644. doi: 10.1371/journal.pone.0057644

Arnold, W. P., Mittal, C. K., Katsuki, S., and Murad, F. (1977). Nitric oxide activates guanylate cyclase and increases guanosine $3^{\prime}: 5^{\prime}$-cyclic monophosphate levels in various tissue preparations. Proc. Natl. Acad. Sci. U.S.A. 74, 3203-3207. doi: 10.1073/pnas.74.8.3203

Baenziger, N. L., Brodie, G. N., and Majerus, P. W. (1971). A thrombin-sensitive protein of human platelet membranes. Proc. Natl. Acad. Sci. U.S.A. 68, 240-243. doi: 10.1073/pnas.68.1.240

Bagavandoss, P., Kaytes, P., Vogeli, G., Wells, P. A., and Wilks, J. W. (1993). Recombinant truncated thrombospondin-1 monomer modulates endothelial cell plasminogen activator inhibitor 1 accumulation and proliferation in vitro. Biochem. Biophys. Res. Commun. 192, 325-332. doi: 10.1006/bbrc.19 93.1418

Balashova, N., Chang, F. J., Lamothe, M., Sun, Q., and Beuve, A. (2005). Characterization of a novel type of endogenous activator of soluble guanylyl cyclase. J. Biol. Chem. 280, 2186-2196. doi: 10.1074/jbc.M411545200

Bamberger, M. E., Harris, M. E., McDonald, D. R., Husemann, J., and Landreth, G. E. (2003). A cell surface receptor complex for fibrillar beta-amyloid mediates microglial activation. J. Neurosci. 23, 2665-2674.

Baskaran, P., Heckler, E. J., van den Akker, F., and Beuve, A. (2011). Identification of residues in the heme domain of soluble guanylyl cyclase that are important for basal and stimulated catalytic activity. PLoS ONE 6:e26976. doi: 10.1371/journal.pone.0026976

Bauer, E. M., Qin, Y., Miller, T. W., Bandle, R. W., Csanyi, G., Pagano, P. J., et al. (2010). Thrombospondin-1 supports blood pressure by limiting eNOS activation and endothelial-dependent vasorelaxation. Cardiovasc. Res. 88, 471-481. doi: $10.1093 / \mathrm{cvr} / \mathrm{cvq} 218$

Bauer, P. M., Bauer, E. M., Rogers, N. M., Yao, M., Feijoo-Cuaresma, M., Pilewski, J. M., et al. (2012). Activated CD47 promotes pulmonary arterial hypertension through targeting caveolin-1. Cardiovasc. Res. 93, 682-693. doi: $10.1093 / \mathrm{cvr} / \mathrm{cvr} 356$

Bauersachs, J., Bouloumie, A., Mulsch, A., Wiemer, G., Fleming, I., and Busse, R. (1998). Vasodilator dysfunction in aged spontaneously hypertensive rats: changes in NO synthase III and soluble guanylyl cyclase expression, and in superoxide anion production. Cardiovasc. Res. 37, 772-779. doi: 10.1016/S00086363(97)00250-2

Bellamy, T. C., Wood, J., Goodwin, D. A., and Garthwaite, J. (2000). Rapid desensitization of the nitric oxide receptor, soluble guanylyl cyclase, underlies diversity of cellular cGMP responses. Proc. Natl. Acad. Sci. U.S.A. 97, 2928-2933. doi: 10.1073/pnas.97.6.2928

Bonnefoy, A., Daenens, K., Feys, H. B., De Vos, R., Vandervoort, P., Vermylen, J., et al. (2006). Thrombospondin-1 controls vascular platelet recruitment and thrombus adherence in mice by protecting (sub)endothelial VWF from cleavage by ADAMTS13. Blood 107, 955-964. doi: 10.1182/blood-200412-4856

Bornstein, P. (2009). Matricellular proteins: an overview. J. Cell Commun. Signal. 3, 163-165. doi: 10.1007/s12079-009-0069-z

Bornstein, P., Devarayalu, S., Li, P., Disteche, C. M., and Framson, P. (1991). A second thrombospondin gene in the mouse is similar in organization to thrombospondin 1 but does not respond to serum. Proc. Natl. Acad. Sci. U.S.A. 88, 8636-8640. doi: 10.1073/pnas.88.19.8636

Brandish, P. E., Buechler, W., and Marletta, M. A. (1998). Regeneration of the ferrous heme of soluble guanylate cyclase from the nitric oxide complex: acceleration by thiols and oxyhemoglobin. Biochemistry 37, 16898-16907. doi: 10.1021/bi9814989

Brandwein, H. J., Lewicki, J. A., and Murad, F. (1981). Reversible inactivation of guanylate cyclase by mixed disulfide formation. J. Biol. Chem. 256, 2958-2962.

Brandwein, H. J., Lewicki, J. A., Waldman, S. A., and Murad, F. (1982). Effect of GTP analogues on purified soluble guanylate cyclase. J. Biol. Chem. 257, 1309-1311. 
Brenman, J. E., Chao, D. S., Gee, S. H., McGee, A. W., Craven, S. E., Santillano, D. R., et al. (1996). Interaction of nitric oxide synthase with the postsynaptic density protein PSD-95 and alphal-syntrophin mediated by PDZ domains. Cell 84, 757-767. doi: 10.1016/S0092-8674(00)81053-3

Brown, E. J., and Frazier, W. A. (2001). Integrin-associated protein (CD47) and its ligands. Trends Cell Biol. 11, 130-135. doi: 10.1016/S0962-8924(00)01906-1

Buechler, W. A., Nakane, M., and Murad, F. (1991). Expression of soluble guanylate cyclase activity requires both enzyme subunits. Biochem. Biophys. Res. Commun. 174, 351-357. doi: 10.1016/0006-291X(91)90527-E

Busker, M., Neidhardt, I., and Behrends, S. (2014). Nitric oxide activation of guanylate cyclase pushes the alphal signaling helix and the betal heme-binding domain closer to the substrate-binding site. J. Biol. Chem. 289, 476-484. doi: 10.1074/jbc.M113.504472

Cai, H., and Harrison, D. G. (2000). Endothelial dysfunction in cardiovascular diseases: the role of oxidant stress. Circ. Res. 87, 840-844. doi: 10.1161/01.RES.87.10.840

Calzada, M. J., Sipes, J. M., Krutzsch, H. C., Yurchenco, P. D., Annis, D. S., Mosher, D. F., et al. (2003). Recognition of the N-terminal modules of thrombospondin-1 and thrombospondin-2 by alpha6betal integrin. J. Biol. Chem. 278, 40679-40687. doi: 10.1074/jbc.M302014200

Campbell, M. G., Underbakke, E. S., Potter, C. S., Carragher, B., and Marletta, M. A. (2014). Single-particle EM reveals the higher-order domain architecture of soluble guanylate cyclase. Proc. Natl. Acad. Sci. U.S.A. 111, 2960-2965. doi: 10.1073/pnas.1400711111

Cannon, J. E., and Pepke-Zaba, J. (2014). Riociguat for pulmonary hypertension. Expert Rev. Clin. Pharmacol. doi: 10.1586/17512433.2014.893818. [Epub ahead of print].

Cary, S. P., Winger, J. A., and Marletta, M. A. (2005). Tonic and acute nitric oxide signaling through soluble guanylate cyclase is mediated by nonheme nitric oxide, ATP, and GTP. Proc. Natl. Acad. Sci. U.S.A. 102, 13064-13069. doi: 10.1073/pnas.0506289102

Chang, F. J., Lemme, S., Sun, Q., Sunahara, R. K., and Beuve, A. (2005). Nitric oxide-dependent allosteric inhibitory role of a second nucleotide binding site in soluble guanylyl cyclase. J. Biol. Chem. 280, 11513-11519. doi: 10.1074/jbc.M412203200

Chen, K., and Keaney, J. F. Jr. (2012). Evolving concepts of oxidative stress and reactive oxygen species in cardiovascular disease. Curr. Atheroscler. Rep. 14, 476-483. doi: 10.1007/s11883-012-0266-8

Chester, M., Seedorf, G., Tourneux, P., Gien, J., Tseng, N., Grover, T., et al. (2011). Cinaciguat, a soluble guanylate cyclase activator, augments cGMP after oxidative stress and causes pulmonary vasodilation in neonatal pulmonary hypertension. Am. J. Physiol. Lung Cell. Mol. Physiol. 301, L755-764. doi: 10.1152/ajplung.00138.2010

Choi, H., Tostes, R. C., and Webb, R. C. (2011). Thioredoxin reductase inhibition reduces relaxation by increasing oxidative stress and snitrosylation in mouse aorta. J. Cardiovasc. Pharmacol. 58, 522-527. doi: 10.1097/FJC.0b013e31822d80a5

Cifuentes, M. E., and Pagano, P. J. (2006). Targeting reactive oxygen species in hypertension. Curr. Opin. Nephrol. Hypertens. 15, 179-186. doi: 10.1097/01.mnh.0000214776.19233.68

Csanyi, G., Yao, M., Rodriguez, A. I., Al Ghouleh, I., Sharifi-Sanjani, M., Frazziano, G., et al. (2012). Thrombospondin-1 regulates blood flow via CD47 receptormediated activation of NADPH oxidase 1. Arterioscler. Thromb. Vasc. Biol. 32, 2966-2973. doi: 10.1161/ATVBAHA.112.300031

Dawson, D. W., Pearce, S. F., Zhong, R., Silverstein, R. L., Frazier, W. A., and Bouck, N. P. (1997). CD36 mediates the in vitro inhibitory effects of thrombospondin1 on endothelial cells. J. Cell Biol. 138, 707-717. doi: 10.1083/jcb. 138.3.707

Derbyshire, E. R., Gunn, A., Ibrahim, M., Spiro, T. G., Britt, R. D., and Marletta, M. A. (2008). Characterization of two different five-coordinate soluble guanylate cyclase ferrous-nitrosyl complexes. Biochemistry 47, 3892-3899. doi: 10.1021/bi7022943

Derbyshire, E. R., and Marletta, M. A. (2012). Structure and regulation of soluble guanylate cyclase. Annu. Rev. Biochem. 81, 533-559. doi: 10.1146/annurevbiochem-050410-100030

Dierks, E., Hu, S., Vogel, K., Yu, A., and Spiro, T. J., B. (1997). Demonstration of the role of scission of the proximal histidine-iron bond in the activation of soluble guanylyl cyclase through metalloporphyrin substitution studies. J. Am. Chem. Soc. 119, 7316-7323. doi: 10.1021/ja9603057
Erbil, W. K., Price, M. S., Wemmer, D. E., and Marletta, M. A. (2009). A structural basis for H-NOX signaling in Shewanella oneidensis by trapping a histidine kinase inhibitory conformation. Proc. Natl. Acad. Sci. U.S.A. 106, 19753-19760. doi: 10.1073/pnas.0911645106

Erdmann, E., Semigran, M. J., Nieminen, M. S., Gheorghiade, M., Agrawal, R., Mitrovic, V., et al. (2013). Cinaciguat, a soluble guanylate cyclase activator, unloads the heart but also causes hypotension in acute decompensated heart failure. Eur. Heart J. 34, 57-67. doi: 10.1093/eurheartj/ehs196

Evgenov, O. V., Pacher, P., Schmidt, P. M., Haskó, G., and Stasch, J. P. (2006). NO-independent stimulators and activators of soluble guanylate cyclase: discovery and therapeutic potential. Nat. Rev. Drug Discov. 5, 755-768. doi: 10.1038/ nrd2038

Favier, J., Germain, S., Emmerich, J., Corvol, P., and Gasc, J. M. (2005). Critical overexpression of thrombospondin 1 in chronic leg ischaemia. J. Pathol. 207, 358-366. doi: 10.1002/path.1833

Fernhoff, N. B., Derbyshire, E. R., and Marletta, M. A. (2009). A nitric oxide/cysteine interaction mediates the activation of soluble guanylate cyclase. Proc. Natl. Acad. Sci. U.S.A. 106, 21602-21607. doi: 10.1073/pnas.0911083106

Ferrero, R., Rodriguez-Pascual, F., Miras-Portugal, M. T., and Torres, M. (2000). Nitric oxide-sensitive guanylyl cyclase activity inhibition through cyclic GMP-dependent dephosphorylation. J. Neurochem. 75, 2029-2039. doi: 10.1046/j.1471-4159.2000.0752029.x

Fritz, B. G., Hu, X., Brailey, J. L., Berry, R. E., Walker, F. A., and Montfort, W. R. (2011). Oxidation and loss of heme in soluble guanylyl cyclase from Manduca sexta. Biochemistry 50, 5813-5815. doi: 10.1021/bi200794c

Fritz, B. G., Roberts, S. A., Ahmed, A., Breci, L., Li, W., Weichsel, A., et al. (2013). Molecular model of a soluble guanylyl cyclase fragment determined by smallangle X-ray scattering and chemical cross-linking. Biochemistry 52, 1568-1582. doi: $10.1021 /$ bi301570m

Gao, S., Hsieh, C. L., Bhansali, M., Kannan, A., and Shemshedini, L. (2013). A peptide against soluble guanylyl cyclase alphal: a new approach to treating prostate cancer. PLoS ONE 8:e64189. doi: 10.1371/journal.pone.0064189

Garthwaite, J., Southam, E., Boulton, C. L., Nielsen, E. B., Schmidt, K., and Mayer, B. (1995). Potent and selective inhibition of nitric oxide-sensitive guanylyl cyclase by $1 \mathrm{H}-[1,2,4]$ oxadiazolo[4,3-a]quinoxalin-1-one. Mol. Pharmacol. 48, 184-188.

Gerassimou, C., Kotanidou, A., Zhou, Z., Simoes, D. C., Roussos, C., and Papapetropoulos, A. (2007). Regulation of the expression of soluble guanylyl cyclase by reactive oxygen species. Br. J. Pharmacol. 150, 1084-1091. doi: 10.1038/sj.bjp.0707179

Gerzer, R., Hofmann, F., and Schultz, G. (1981). Purification of a soluble, sodiumnitroprusside-stimulated guanylate cyclase from bovine lung. Eur. J. Biochem. 116, 479-486. doi: 10.1111/j.1432-1033.1981.tb05361.x

Ghofrani, H. A., Galie, N., Grimminger, F., Grunig, E., Humbert, M., Jing, Z. C., et al. (2013). Riociguat for the treatment of pulmonary arterial hypertension. $N$. Engl. J. Med. 369, 330-340. doi: 10.1056/NEJMoa1209655

Ghosh, A., and Stuehr, D. J. (2012). Soluble guanylyl cyclase requires heat shock protein 90 for heme insertion during maturation of the NO-active enzyme. Proc. Natl. Acad. Sci. U.S.A. 109, 12998-13003. doi: 10.1073/pnas.1205854109

Gille, A., Lushington, G. H., Mou, T. C., Doughty, M. B., Johnson, R. A., and Seifert, R. (2004). Differential inhibition of adenylyl cyclase isoforms and soluble guanylyl cyclase by purine and pyrimidine nucleotides. J. Biol. Chem. 279, 19955-19969. doi: 10.1074/jbc.M312560200

Good, D. J., Polverini, P. J., Rastinejad, F., Le Beau, M. M., Lemons, R. S., Frazier, W. A., et al. (1990). A tumor suppressor-dependent inhibitor of angiogenesis is immunologically and functionally indistinguishable from a fragment of thrombospondin. Proc. Natl. Acad. Sci. U.S.A. 87, 6624-6628. doi: 10.1073/pnas.87.17.6624

Goodrich, L. E., Paulat, F., Praneeth, V. K., and Lehnert, N. (2010). Electronic structure of heme-nitrosyls and its significance for nitric oxide reactivity, sensing, transport, and toxicity in biological systems. Inorg. Chem. 49, 6293-6316. doi: 10.1021/ic902304a

Gruetter, C. A., Kadowitz, P. J., and Ignarro, L. J. (1981). Methylene blue inhibits coronary arterial relaxation and guanylate cyclase activation by nitroglycerin, sodium nitrite, and amyl nitrite. Can. J. Physiol. Pharmacol. 59, 150-156. doi: 10.1139/y81-025

Guo, N., Krutzsch, H. C., Inman, J. K., and Roberts, D. D. (1997). Thrombospondin 1 and type I repeat peptides of thrombospondin 1 specifically induce apoptosis of endothelial cells. Cancer Res. 57, 1735-1742. 
Gupta, G., Azam, M., Yang, L., and Danziger, R. S. (1997). The beta2 subunit inhibits stimulation of the alphal/betal form of soluble guanylyl cyclase by nitric oxide. Potential relevance to regulation of blood pressure. J. Clin. Invest. 100, 1488-1492. doi: 10.1172/JCI119670

Haase, T., Haase, N., Kraehling, J. R., and Behrends, S. (2010). Fluorescent fusion proteins of soluble guanylyl cyclase indicate proximity of the heme nitric oxide domain and catalytic domain. PLOS ONE 5:e11617. doi: 10.1371/journal.pone.0011617

Heckler, E. J., Crassous, P. A., Baskaran, P., and Beuve, A. (2013). Protein disulfideisomerase interacts with soluble guanylyl cyclase via a redox-based mechanism and modulates its activity. Biochem. J. 452, 161-169. doi: 10.1042/BJ20130298

Iruela-Arispe, M. L., Lombardo, M., Krutzsch, H. C., Lawler, J., and Roberts, D. D. (1999). Inhibition of angiogenesis by thrombospondin-1 is mediated by 2 independent regions within the type 1 repeats. Circulation 100, 1423-1431. doi: 10.1161/01.CIR.100.13.1423

Isenberg, J. S., Annis, D. S., Pendrak, M. L., Ptaszynska, M., Frazier, W. A., Mosher, D. F., et al. (2009a). Differential interactions of thrombospondin-1, -2 , and -4 with CD47 and effects on cGMP signaling and ischemic injury responses. J. Biol. Chem. 284, 1116-1125. doi: 10.1074/jbc.M804860200

Isenberg, J. S., Frazier, W. A., Krishna, M. C., Wink, D. A., and Roberts, D. D. (2008a). Enhancing cardiovascular dynamics by inhibition of thrombospondin-1/CD47 signaling. Curr. Drug Targets 9, 833-841. doi: 10.2174/138945008785909338

Isenberg, J. S., Hyodo, F., Matsumoto, K., Romeo, M. J., Abu-Asab, M., Tsokos, M., et al. (2007a). Thrombospondin-1 limits ischemic tissue survival by inhibiting nitric oxide-mediated vascular smooth muscle relaxation. Blood 109, 1945-1952. doi: 10.1182/blood-2006-08-041368

Isenberg, J. S., Hyodo, F., Pappan, L. K., Abu-Asab, M., Tsokos, M., Krishna, M. C., et al. (2007b). Blocking thrombospondin-1/CD47 signaling alleviates deleterious effects of aging on tissue responses to ischemia. Arterioscler. Thromb. Vasc. Biol. 27, 2582-2588. doi: 10.1161/ATVBAHA.107.155390

Isenberg, J. S., Jia, Y., Fukuyama, J., Switzer, C. H., Wink, D. A., and Roberts, D. D. (2007c). Thrombospondin-1 inhibits nitric oxide signaling via CD36 by inhibiting myristic acid uptake. J. Biol. Chem. 282, 15404-15415. doi: 10.1074/jbc.M701638200

Isenberg, J. S., Martin-Manso, G., Maxhimer, J. B., and Roberts, D. D. (2009b). Regulation of nitric oxide signalling by thrombospondin 1: implications for anti-angiogenic therapies. Nat. Rev. Cancer 9, 182-194. doi: 10.1038/nrc2561

Isenberg, J. S., Maxhimer, J. B., Powers, P., Tsokos, M., Frazier, W. A., and Roberts, D. D. (2008b). Treatment of liver ischemia-reperfusion injury by limiting thrombospondin-1/CD47 signaling. Surgery 144, 752-761. doi: 10.1016/j.surg.2008.07.009

Isenberg, J. S., Pappan, L. K., Romeo, M. J., Abu-Asab, M., Tsokos, M., Wink, D. A., et al. (2008c). Blockade of thrombospondin-1-CD47 interactions prevents necrosis of full thickness skin grafts. Ann. Surg. 247, 180-190. doi: 10.1097/SLA.0b013e31815685dc

Isenberg, J. S., Qin, Y., Maxhimer, J. B., Sipes, J. M., Despres, D., Schnermann, J., et al. (2009c). Thrombospondin-1 and CD47 regulate blood pressure and cardiac responses to vasoactive stress. Matrix Biol. 28, 110-119. doi: 10.1016/j.matbio.2009.01.002

Isenberg, J. S., Ridnour, L. A., Dimitry, J., Frazier, W. A., Wink, D. A., and Roberts, D. D. (2006a). CD47 is necessary for inhibition of nitric oxide-stimulated vascular cell responses by thrombospondin-1. J. Biol. Chem. 281, 26069-26080. doi: 10.1074/jbc.M605040200

Isenberg, J. S., Ridnour, L. A., Espey, M. G., Wink, D. A., and Roberts, D. D. (2005a). Nitric oxide in wound-healing. Microsurgery 25, 442-451. doi: 10.1002/micr.20168

Isenberg, J. S., Ridnour, L. A., Perruccio, E. M., Espey, M. G., Wink, D. A., and Roberts, D. D. (2005b). Thrombospondin-1 inhibits endothelial cell responses to nitric oxide in a cGMP-dependent manner. Proc. Natl. Acad. Sci. U.S.A. 102, 13141-13146. doi: 10.1073/pnas.0502977102

Isenberg, J. S., Romeo, M. J., Abu-Asab, M., Tsokos, M., Oldenborg, A., Pappan, L., et al. (2007d). Increasing survival of ischemic tissue by targeting CD47. Circ. Res. 100, 712-720. doi: 10.1161/01.RES.0000259579.35787.4e

Isenberg, J. S., Romeo, M. J., Maxhimer, J. B., Smedley, J., Frazier, W. A., and Roberts, D. D. (2008d). Gene silencing of CD47 and antibody ligation of thrombospondin-1 enhance ischemic tissue survival in a porcine model: implications for human disease. Ann. Surg. 247, 860-868. doi: 10.1097/SLA.0b013e31816c4006
Isenberg, J. S., Romeo, M. J., Yu, C., Yu, C. K., Nghiem, K., Monsale, J., et al. (2008e). Thrombospondin-1 stimulates platelet aggregation by blocking the antithrombotic activity of nitric oxide/cGMP signaling. Blood 111, 613-623. doi: 10.1182/blood-2007-06-098392

Isenberg, J. S., Shiva, S., and Gladwin, M. (2009d). Thrombospondin-1-CD47 blockade and exogenous nitrite enhance ischemic tissue survival, blood flow and angiogenesis via coupled NO-cGMP pathway activation. Nitric Oxide 21, 52-62. doi: 10.1016/j.niox.2009.05.005

Isenberg, J. S., Wink, D. A., and Roberts, D. D. (2006b). Thrombospondin-1 antagonizes nitric oxide-stimulated vascular smooth muscle cell responses. Cardiovasc. Res. 71, 785-793. doi: 10.1016/j.cardiores.2006.05.024

Isenberg, J. S., Yu, C., and Roberts, D. D. (2008f). Differential effects of ABT-510 and a CD36-binding peptide derived from the type 1 repeats of thrombospondin-1 on fatty acid uptake, nitric oxide signaling, and caspase activation in vascular cells. Biochem. Pharmacol. 75, 875-882. doi: 10.1016/j.bcp.2007.10.025

James, L. R., Griffiths, C. H., Garthwaite, J., and Bellamy, T. C. (2009). Inhibition of nitric oxide-activated guanylyl cyclase by calmodulin antagonists. Br. J. Pharmacol. 158, 1454-1464. doi: 10.1111/j.1476-5381.2009. 00416.x

Jimenez, B., Volpert, O. V., Reiher, F., Chang, L., Munoz, A., Karin, M., et al. (2001). c-Jun N-terminal kinase activation is required for the inhibition of neovascularization by thrombospondin-1. Oncogene 20, 3443-3448. doi: 10.1038/sj.onc.1204464

Kaur, S., Martin-Manso, G., Pendrak, M. L., Garfield, S. H., Isenberg, J. S., and Roberts, D. D. (2010). Thrombospondin-1 inhibits VEGF receptor-2 signaling by disrupting its association with CD47. J. Biol. Chem. 285, 38923-38932. doi: 10.1074/jbc.M110.172304

Kaur, S., Soto-Pantoja, D. R., Stein, E. V., Liu, C., Elkahloun, A. G., Pendrak, M. L., et al. (2013). Thrombospondin-1 signaling through CD47 inhibits self-renewal by regulating c-Myc and other stem cell transcription factors. Sci. Rep. 3:1673. doi: 10.1038/srep01673

Kazerounian, S., Pitari, G. M., Ruiz-Stewart, I., Schulz, S., and Waldman, S. A. (2002). Nitric oxide activation of soluble guanylyl cyclase reveals high and low affinity sites that mediate allosteric inhibition by calcium. Biochemistry 41 , 3396-3404. doi: 10.1021/bi0110894

Kelm, M., and Schrader, J. (1990). Control of coronary vascular tone by nitric oxide. Circ. Res. 66, 1561-1575. doi: 10.1161/01.RES.66.6.1561

Kharitonov, V. G., Sharma, V. S., Magde, D., and Koesling, D. (1997). Kinetics of nitric oxide dissociation from five- and six-coordinate nitrosyl hemes and heme proteins, including soluble guanylate cyclase. Biochemistry 36, 6814-6818. doi: 10.1021/bi970201o

Kondo, K., Bhushan, S., King, A. L., Prabhu, S. D., Hamid, T., Koenig, S., et al. (2013). H(2)S protects against pressure overload-induced heart failure via upregulation of endothelial nitric oxide synthase. Circulation 127, 1116-1127. doi: 10.1161/CIRCULATIONAHA.112.000855

Kopp, H. G., Hooper, A. T., Broekman, M. J., Avecilla, S. T., Petit, I., Luo, M., et al. (2006). Thrombospondins deployed by thrombopoietic cells determine angiogenic switch and extent of revascularization. J. Clin. Invest. 116, 3277-3291. doi: 10.1172/JCI29314

Kram, L., Grambow, E., Mueller-Graf, F., Sorg, H., and Vollmar, B. (2013). The anti-thrombotic effect of hydrogen sulfide is partly mediated by an upregulation of nitric oxide synthases. Thromb. Res. 132, e112-117. doi: 10.1016/j.thromres.2013.07.010

Kumar, V., Martin, F., Hahn, M. G., Schaefer, M., Stamler, J. S., Stasch, J. P., et al. (2013). Insights into BAY 60-2770 activation and s-nitrosylation-dependent desensitization of soluble guanylyl cyclase via crystal structures of homologous nostoc H-NOX domain complexes. Biochemistry 52, 3601-3608. doi: 10.1021/bi301657w

Lawler, J. W., Slayter, H. S., and Coligan, J. E. (1978). Isolation and characterization of a high molecular weight glycoprotein from human blood platelets. J. Biol. Chem. 253, 8609-8616.

Lawler, P. R., and Lawler, J. (2012). Molecular basis for the regulation of angiogenesis by thrombospondin-1 and -2. Cold Spring Harb. Perspect. Med. 2:a006627. doi: $10.1101 /$ cshperspect.a006627

Lincoln, T. M., and Cornwell, T. L. (1993). Intracellular cyclic GMP receptor proteins. FASEB J. 7, 328-338.

Linder, A. E., McCluskey, L. P., Cole, K. R. 3rd., Lanning, K. M., and Webb, R. C. (2005). Dynamic association of nitric oxide downstream signaling molecules 
with endothelial caveolin-1 in rat aorta. J. Pharmacol. Exp. Ther. 314, 9-15. doi: 10.1124/jpet.105.083634

Loscalzo, J. (2001). Nitric oxide insufficiency, platelet activation, and arterial thrombosis. Circ. Res. 88, 756-762. doi: 10.1161/hh0801. 089861

Louis, J. C., Revel, M. O., and Zwiller, J. (1993). Activation of soluble guanylate cyclase through phosphorylation by protein kinase C in intact PC12 cells. Biochim. Biophys. Acta 1177, 299-306. doi: 10.1016/0167-4889(93)90126-A

Lucas, K. A., Pitari, G. M., Kazerounian, S., Ruiz-Stewart, I., Park, J., Schulz, S., et al. (2000). Guanylyl cyclases and signaling by cyclic GMP. Pharmacol. Rev. 52, 375-414.

Lundberg, J. O., Weitzberg, E., and Gladwin, M. T. (2008). The nitrate-nitritenitric oxide pathway in physiology and therapeutics. Nat. Rev. Drug Discov. 7, 156-167. doi: 10.1038/nrd2466

Ma, X., Beuve, A., and van den Akker, F. (2010). Crystal structure of the signaling helix coiled-coil domain of the betal subunit of the soluble guanylyl cyclase. BMC Struct. Biol. 10:2. doi: 10.1186/1472-6807-10-2

Ma, X., Sayed, N., Baskaran, P., Beuve, A., and van den Akker, F. (2008). PASmediated dimerization of soluble guanylyl cyclase revealed by signal transduction histidine kinase domain crystal structure. J. Biol. Chem. 283, 1167-1178. doi: 10.1074/jbc.M706218200

Ma, X., Sayed, N., Beuve, A., and van den Akker, F. (2007). NO and CO differentially activate soluble guanylyl cyclase via a heme pivot-bend mechanism. EMBO J. 26, 578-588. doi: 10.1038/sj.emboj.7601521

MacLauchlan, S., Yu, J., Parrish, M., Asoulin, T. A., Schleicher, M., Krady, M. M., et al. (2011). Endothelial nitric oxide synthase controls the expression of the angiogenesis inhibitor thrombospondin 2. Proc. Natl. Acad. Sci. U.S.A. 108, E1137-E1145. doi: 10.1073/pnas.1104357108

Majack, R. A., Cook, S. C., and Bornstein, P. (1986). Control of smooth muscle cell growth by components of the extracellular matrix: autocrine role for thrombospondin. Proc. Natl. Acad. Sci. U.S.A. 83, 9050-9054. doi: 10.1073/pnas.83.23.9050

Margulis, A., and Sitaramayya, A. (2000). Rate of deactivation of nitric oxidestimulated soluble guanylate cyclase: influence of nitric oxide scavengers and calcium. Biochemistry 39, 1034-1039. doi: 10.1021/bi992040p

Martin, F., Baskaran, P., Ma, X., Dunten, P. W., Schaefer, M., Stasch, J. P., et al. (2010). Structure of cinaciguat (BAY 58-2667) bound to Nostoc HNOX domain reveals insights into heme-mimetic activation of the soluble guanylyl cyclase. J. Biol. Chem. 285, 22651-22657. doi: 10.1074/jbc.M110. 111559

Mateo, V., Brown, E. J., Biron, G., Rubio, M., Fischer, A., Deist, F. L., et al. (2002). Mechanisms of CD47-induced caspase-independent cell death in normal and leukemic cells: link between phosphatidylserine exposure and cytoskeleton organization. Blood 100, 2882-2890. doi: 10.1182/blood-2001-12-0217

Maxhimer, J. B., Shih, H. B., Isenberg, J. S., Miller, T. W., and Roberts, D. D. (2009). Thrombospondin-1/CD47 blockade following ischemia-reperfusion injury is tissue protective. Plast. Reconstr. Surg. 124, 1880-1889. doi: 10.1097/PRS.0b013e3181bceec3

Mayer, B., Kleschyov, A. L., Stessel, H., Russwurm, M., Munzel, T., Koesling, D., et al. (2009). Inactivation of soluble guanylate cyclase by stoichiometric S-nitrosation. Mol. Pharmacol. 75, 886-891. doi: 10.1124/mol.108.052142

McDonald, J. F., Dimitry, J. M., and Frazier, W. A. (2003). An amyloid-like Cterminal domain of thrombospondin-1 displays $\mathrm{CD} 47$ agonist activity requiring both VVM motifs. Biochemistry 42, 10001-10011. doi: 10.1021/bi0341408

Mendes-Silverio, C. B., Leiria, L. O., Morganti, R. P., Anhe, G. F., Marcondes, S., Monica, F. Z., et al. (2012). Activation of haem-oxidized soluble guanylyl cyclase with BAY 60-2770 in human platelets lead to overstimulation of the cyclic GMP signaling pathway. PLoS ONE 7:e47223. doi: 10.1371/journal.pone.0047223

Meng, J., Ganesan Adaikan, P., and Srilatha, B. (2013). Hydrogen sulfide promotes nitric oxide production in corpus cavernosum by enhancing expression of endothelial nitric oxide synthase. Int. J. Impot. Res. 25, 86-90. doi: 10.1038/ijir.2012.39

Mergia, E., Russwurm, M., Zoidl, G., and Koesling, D. (2003). Major occurrence of the new alpha2betal isoform of NO-sensitive guanylyl cyclase in brain. Cell. Signal. 15, 189-195. doi: 10.1016/S0898-6568(02)00078-5

Meurer, S., Pioch, S., Gross, S., and Muller-Esterl, W. (2005). Reactive oxygen species induce tyrosine phosphorylation of and Src kinase recruitment to NO-sensitive guanylyl cyclase. J. Biol. Chem. 280, 33149-33156. doi: 10.1074/jbc.M507565200
Meurer, S., Pioch, S., Wagner, K., Muller-Esterl, W., and Gross, S. (2004). AGAP1, a novel binding partner of nitric oxide-sensitive guanylyl cyclase. J. Biol. Chem. 279, 49346-49354. doi: 10.1074/jbc.M410565200

Miller, T. W., Isenberg, J. S., and Roberts, D. D. (2009). Molecular regulation of tumor angiogenesis and perfusion via redox signaling. Chem. Rev. 109, 3099-3124. doi: 10.1021/cr8005125

Miller, T. W., Isenberg, J. S., and Roberts, D. D. (2010a). Thrombospondin-1 is an inhibitor of pharmacological activation of soluble guanylate cyclase. $\mathrm{Br}$. J. Pharmacol. 159, 1542-1547. doi: 10.1111/j.1476-5381.2009.00631.x

Miller, T. W., Isenberg, J. S., Shih, H. B., Wang, Y., and Roberts, D. D. (2010b). Amyloid-beta inhibits No-cGMP signaling in a CD36- and CD47-dependent manner. PLoS ONE 5:e15686. doi: 10.1371/journal.pone.0015686

Miller, T. W., Kaur, S., Ivins-O'Keefe, K., and Roberts, D. D. (2013). Thrombospondin-1 is a CD47-dependent endogenous inhibitor of hydrogen sulfide signaling in $\mathrm{T}$ cell activation. Matrix Biol. 32, 316-324. doi: 10.1016/j.matbio.2013.02.009

Miller, T. W., Wang, E. A., Gould, S., Stein, E. V., Kaur, S., Lim, L., et al. (2012). Hydrogen sulfide is an endogenous potentiator of T cell activation. J. Biol. Chem. 287, 4211-4221. doi: 10.1074/jbc.M111.307819

Mingone, C. J., Gupte, S. A., Ali, N., Oeckler, R. A., and Wolin, M. S. (2006). Thiol oxidation inhibits nitric oxide-mediated pulmonary artery relaxation and guanylate cyclase stimulation. Am. J. Physiol. Lung Cell. Mol. Physiol. 290, L549-557. doi: 10.1152/ajplung.00331.2005

Mitrovic, V., Jovanovic, A., and Lehinant, S. (2011). Soluble guanylate cyclase modulators in heart failure. Curr. Heart Fail. Rep. 8, 38-44. doi: 10.1007/s11897010-0045-1

Mittendorf, J., Weigand, S., Alonso-Alija, C., Bischoff, E., Feurer, A., Gerisch, M., et al. (2009). Discovery of riociguat (BAY 63-2521): a potent, oral stimulator of soluble guanylate cyclase for the treatment of pulmonary hypertension. ChemMedChem 4, 853-865. doi: 10.1002/cmdc.200900014

Moncada, S., and Higgs, A. (1993). The L-arginine-nitric oxide pathway. N. Engl. J. Med. 329, 2002-2012. doi: 10.1056/NEJM199312303292706

Mosher, D. F., and Adams, J. C. (2012). Adhesion-modulating/matricellular ECM protein families: a structural, functional and evolutionary appraisal. Matrix Biol. 31, 155-161. doi: 10.1016/j.matbio.2012.01.003

Moustafa, A., and Habara, Y. (2014). Hydrogen sulfide regulates $\mathrm{Ca}(2+)$ homeostasis mediated by concomitantly produced nitric oxide via a novel synergistic pathway in exocrine pancreas. Antioxid. Redox Signal. 20, 747-758. doi: 10.1089/ ars.2012.5108

Mulsch, A., Busse, R., and Bassenge, E. (1988). Desensitization of guanylate cyclase in nitrate tolerance does not impair endothelium-dependent responses. Eur. J. Pharmacol. 158, 191-198. doi: 10.1016/0014-2999(88)90066-0

Munzel, T., Daiber, A., and Mulsch, A. (2005). Explaining the phenomenon of nitrate tolerance. Circ. Res. 97, 618-628. doi: 10.1161/01.RES.0000184694. $03262.6 \mathrm{~d}$

Munzel, T., Feil, R., Mulsch, A., Lohmann, S. M., Hofmann, F., and Walter, U. (2003). Physiology and pathophysiology of vascular signaling controlled by guanosine $3^{\prime}, 5^{\prime}$-cyclic monophosphate-dependent protein kinase [corrected]. Circulation 108, 2172-2183. doi: 10.1161/01.CIR.0000094403.78467.C3

Murad, F., Mittal, C. K., Arnold, W. P., Katsuki, S., and Kimura, H. (1978). Guanylate cyclase: activation by azide, nitro compounds, nitric oxide, and hydroxyl radical and inhibition by hemoglobin and myoglobin. Adv. Cyclic Nucleotide Res. 9, 145-158.

Murad, F., Rapoport, R. M., and Fiscus, R. (1985). Role of cyclic-GMP in relaxations of vascular smooth muscle. J. Cardiovasc. Pharmacol. 7(Suppl. 3), S111-S118. doi: 10.1097/00005344-198500073-00013

Murthy, K. S. (2004). Modulation of soluble guanylate cyclase activity by phosphorylation. Neurochem. Int. 45, 845-851. doi: 10.1016/j.neuint.2004.03.014

Murthy, K. S. (2008). Inhibitory phosphorylation of soluble guanylyl cyclase by muscarinic $\mathrm{m} 2$ receptors via Gbetagamma-dependent activation of $\mathrm{c}$ Src kinase. J. Pharmacol. Exp. Ther. 325, 183-189. doi: 10.1124/jpet.107. 132928

Mwaikambo, B. R., Sennlaub, F., Ong, H., Chemtob, S., and Hardy, P. (2006). Activation of CD36 inhibits and induces regression of inflammatory corneal neovascularization. Invest. Ophthalmol. Vis. Sci. 47, 4356-4364. doi: 10.1167/iovs.05-1656

Narizhneva, N. V., Byers-Ward, V. J., Quinn, M. J., Zidar, F. J., Plow, E. F., Topol, E. J., et al. (2004). Molecular and functional differences induced in thrombospondin-1 by the single nucleotide polymorphism associated with 
the risk of premature, familial myocardial infarction. J. Biol. Chem. 279, 21651-21657. doi: 10.1074/jbc.M311090200

Nioche, P., Berka, V., Vipond, J., Minton, N., Tsai, A. L., and Raman, C. S. (2004). Femtomolar sensitivity of a NO sensor from Clostridium botulinum. Science 306, 1550-1553. doi: 10.1126/science.1103596

Novelli, E. M., Kato, G. J., Ragni, M. V., Zhang, Y., Hildesheim, M. E., Nouraie, M., et al. (2012). Plasma thrombospondin-1 is increased during acute sickle cell vaso-occlusive events and associated with acute chest syndrome, hydroxyurea therapy, and lower hemolytic rates. Am. J. Hematol. 87, 326-330. doi: 10.1002/ajh.22274

Oldenborg, P. A., Zheleznyak, A., Fang, Y. F., Lagenaur, C. F., Gresham, H. D., and Lindberg, F. P. (2000). Role of CD47 as a marker of self on red blood cells. Science 288, 2051-2054. doi: 10.1126/science.288.5473.2051

Olea, C., Boon, E. M., Pellicena, P., Kuriyan, J., and Marletta, M. A. (2008). Probing the function of heme distortion in the H-NOX family. ACS Chem. Biol. 3, 703-710. doi: 10.1021/cb800185h

Olea, C. Jr., Herzik, M. A. Jr., Kuriyan, J., and Marletta, M. A. (2010). Structural insights into the molecular mechanism of H-NOX activation. Protein Sci. 19, 881-887. doi: 10.1002/pro.357

Pal, B., and Kitagawa, T. (2010). Binding of YC-1/BAY 41-2272 to soluble guanylate cyclase: A new perspective to the mechanism of activation. Biochem. Biophys. Res. Commun. 397, 375-379. doi: 10.1016/j.bbrc.2010.05.122

Parkinson, S. J., Jovanovic, A., Jovanovic, S., Wagner, F., Terzic, A., and Waldman, S. A. (1999). Regulation of nitric oxide-responsive recombinant soluble guanylyl cyclase by calcium. Biochemistry 38, 6441-6448. doi: 10.1021/ bi990154y

Pellicena, P., Karow, D. S., Boon, E. M., Marletta, M. A., and Kuriyan, J. (2004). Crystal structure of an oxygen-binding heme domain related to soluble guanylate cyclases. Proc. Natl. Acad. Sci. U.S.A. 101, 12854-12859. doi: 10.1073/pnas.0405188101

Piatakova, N. V., and Severina, I. S. (2012). [Soluble guanylate cyclase in the molecular mechanism underlying the therapeutic action of drugs]. Biomed. Khim. 58, 32-42. doi: 10.1134/S1990750812040075

Purohit, R., Fritz, B. G., The, J., Issaian, A., Weichsel, A., David, C. L., et al. (2014). YC-1 Binding to the beta subunit of soluble guanylyl cyclase overcomes allosteric inhibition by the alpha subunit. Biochemistry 53, 101-114. doi: 10.1021/bi4015133

Purohit, R., Weichsel, A., and Montfort, W. R. (2013). Crystal structure of the Alpha subunit PAS domain from soluble guanylyl cyclase. Protein Sci. 22, 1439-1444. doi: $10.1002 /$ pro. 2331

Rabinovitch, M. (2007). Pathobiology of pulmonary hypertension. Annu. Rev. Pathol. 2, 369-399. doi: 10.1146/annurev.pathol.2.010506.092033

Ramanathan, S., Mazzalupo, S., Boitano, S., and Montfort, W. R. (2011) Thrombospondin-1 and angiotensin II inhibit soluble guanylyl cyclase through an increase in intracellular calcium concentration. Biochemistry 50, 7787-7799. doi: 10.1021/bi201060c

Rauch, A., Leipelt, M., Russwurm, M., and Steegborn, C. (2008). Crystal structure of the guanylyl cyclase Cya2. Proc. Natl. Acad. Sci. U.S.A. 105, 15720-15725. doi: 10.1073/pnas.0808473105

Rindone, J. P., and Sloane, E. P. (1992). Cyanide toxicity from sodium nitroprusside: risks and management. Ann. Pharmacother. 26, 515-519.

Rogers, N. M., Roberts, D. D., and Isenberg, J. S. (2013). Age-associated induction of cell membrane CD47 limits basal and temperatureinduced changes in cutaneous blood flow. Ann. Surg. 258, 184-191. doi: 10.1097/SLA.0b013e31827e52e1

Rogers, N. M., Thomson, A. W., and Isenberg, J. S. (2012). Activation of parenchymal CD47 promotes renal ischemia-reperfusion injury. J. Am. Soc. Nephrol. 23, 1538-1550. doi: 10.1681/ASN.2012020137

Ruiz-Stewart, I., Tiyyagura, S. R., Lin, J. E., Kazerounian, S., Pitari, G. M., Schulz, S., et al. (2004). Guanylyl cyclase is an ATP sensor coupling nitric oxide signaling to cell metabolism. Proc. Natl. Acad. Sci. U.S.A. 101, 37-42. doi: 10.1073/pnas.0305080101

Russwurm, M., and Koesling, D. (2004). NO activation of guanylyl cyclase. EMBO J. 23, 4443-4450. doi: 10.1038/sj.emboj.7600422

Russwurm, M., Mergia, E., Mullershausen, F., and Koesling, D. (2002). Inhibition of deactivation of NO-sensitive guanylyl cyclase accounts for the sensitizing effect of YC-1. J. Biol. Chem. 277, 24883-24888. doi: 10.1074/jbc.M110570200

Russwurm, M., Wittau, N., and Koesling, D. (2001). Guanylyl cyclase/PSD95 interaction: targeting of the nitric oxide-sensitive alpha2betal guanylyl cyclase to synaptic membranes. J. Biol. Chem. 276, 44647-44652. doi: 10.1074/jbc.M105587200

Sayed, N., Baskaran, P., Ma, X., van den Akker, F., and Beuve, A. (2007). Desensitization of soluble guanylyl cyclase, the NO receptor, by S-nitrosylation. Proc. Natl. Acad. Sci. U.S.A. 104, 12312-12317. doi: 10.1073/pnas.0703944104

Sayed, N., Kim, D. D., Fioramonti, X., Iwahashi, T., Duran, W. N., and Beuve, A. (2008). Nitroglycerin-induced S-nitrosylation and desensitization of soluble guanylyl cyclase contribute to nitrate tolerance. Circ. Res. 103, 606-614. doi: 10.1161/CIRCRESAHA.108.175133

Scheef, E. A., Sorenson, C. M., and Sheibani, N. (2009). Attenuation of proliferation and migration of retinal pericytes in the absence of thrombospondin-1. Am. J. Physiol. Cell Physiol. 296, C724-C734. doi: 10.1152/ajpcell.00409.2008

Schermuly, R. T., Janssen, W., Weissmann, N., Stasch, J. P., Grimminger, F., and Ghofrani, H. A. (2011). Riociguat for the treatment of pulmonary hypertension. Expert Opin. Investig. Drugs 20, 567-576. doi: 10.1517/13543784.2011.565048

Schrammel, A., Behrends, S., Schmidt, K., Koesling, D., and Mayer, B. (1996). Characterization of $1 \mathrm{H}-[1,2,4]$ oxadiazolo[4,3-a]quinoxalin-1-one as a hemesite inhibitor of nitric oxide-sensitive guanylyl cyclase. Mol. Pharmacol. $50,1-5$.

Schroder, H., Leitman, D. C., Bennett, B. M., Waldman, S. A., and Murad, F. (1988). Glyceryl trinitrate-induced desensitization of guanylate cyclase in cultured rat lung fibroblasts. J. Pharmacol. Exp. Ther. 245, 413-418.

Schwartz, M. A., Brown, E. J., and Fazeli, B. (1993). A 50-kDa integrin-associated protein is required for integrin-regulated calcium entry in endothelial cells. J. Biol. Chem. 268, 19931-19934.

Seeger, F., Quintyn, R., Tanimoto, A., Williams, G. J., Tainer, J. A., Wysocki, V. W., et al. (2014). Interfacial Residues promote an optimal alignment of the catalytic center in human soluble guanylate cyclase: heterodimerization is required but not sufficient for activity. Biochemistry. doi: 10.102/bi500129k. [Epub ahead print].

Serfass, L., Carr, H. S., Aschenbrenner, L. M., and Burstyn, J. N. (2001). Calcium ion downregulates soluble guanylyl cyclase activity: evidence for a two-metal ion catalytic mechanism. Arch. Biochem. Biophys. 387, 47-56. doi: 10.1006/abbi.2000.2090

Sick, E., Niederhoffer, N., Takeda, K., Landry, Y., and Gies, J. P. (2009). Activation of CD47 receptors causes histamine secretion from mast cells. Cell. Mol. Life Sci. 66, 1271-1282. doi: 10.1007/s00018-009-8778-2

Smadja, D. M., d'Audigier, C., Bieche, I., Evrard, S., Mauge, L., Dias, J. V., et al. (2011). Thrombospondin-1 is a plasmatic marker of peripheral arterial disease that modulates endothelial progenitor cell angiogenic properties. Arterioscler. Thromb. Vasc. Biol. 31, 551-559. doi: 10.1161/ATVBAHA.110. 220624

Stasch, J. P., and Evgenov, O. V. (2013). Soluble guanylate cyclase stimulators in pulmonary hypertension. Handb. Exp. Pharmacol. 218, 279-313. doi: 10.1007/978-3-642-38664-0_12

Stasch, J. P., Pacher, P., and Evgenov, O. V. (2011). Soluble guanylate cyclase as an emerging therapeutic target in cardiopulmonary disease. Circulation 123, 2263-2273. doi: 10.1161/CIRCULATIONAHA.110.981738

Stasch, J. P., Schmidt, P. M., Nedvetsky, P. I., Nedvetskaya, T. Y. H. S. A., Meurer, S., et al. (2006). Targeting the heme-oxidized nitric oxide receptor for selective vasodilatation of diseased blood vessels. J. Clin. Invest. 116, 2552-2561. doi: 10.1172/JCI28371

Stenina, O. I., Ustinov, V., Krukovets, I., Marinic, T., Topol, E. J., and Plow, E. F. (2005). Polymorphisms A387P in thrombospondin-4 and N700S in thrombospondin-1 perturb calcium binding sites. FASEB J. 19, 1893-1895.

Stone, J. R., and Marletta, M. A. (1996). Spectral and kinetic studies on the activation of soluble guanylate cyclase by nitric oxide. Biochemistry 35, 1093-1099. doi: $10.1021 /$ bi9519718

Stone, J. R., Sands, R. H., Dunham, W. R., and Marletta, M. A. (1995). Electron paramagnetic resonance spectral evidence for the formation of a pentacoordinate nitrosyl-heme complex on soluble guanylate cyclase. Biochem. Biophys. Res. Commun. 207, 572-577. doi: 10.1006/bbrc.1995.1226

Taraboletti, G., Roberts, D., Liotta, L. A., and Giavazzi, R. (1990). Platelet thrombospondin modulates endothelial cell adhesion, motility, and growth: a potential angiogenesis regulatory factor. J. Cell Biol. 111, 765-772. doi: 10.1083/jcb.111.2.765

Thomas, D. D., Ridnour, L. A., Espey, M. G., Donzelli, S., Ambs, S., Hussain, S. P., et al. (2006). Superoxide fluxes limit nitric oxide-induced signaling. J. Biol. Chem. 281, 25984-25993. doi: 10.1074/jbc.M602242200 
Tolsma, S. S., Volpert, O. V., Good, D. J., Frazier, W. A., Polverini, P. J., and Bouck, N. (1993). Peptides derived from two separate domains of the matrix protein thrombospondin-1 have anti-angiogenic activity. J. Cell Biol. 122, 497-511. doi: 10.1083/jcb.122.2.497

Tsai, A. L., Berka, V., Sharina, I., and Martin, E. (2011). Dynamic ligand exchange in soluble guanylyl cyclase (sGC): implications for sGC regulation and desensitization. J. Biol. Chem. 286, 43182-43192. doi: 10.1074/jbc.M111.290304

Tsai, A. L., Martin, E., Berka, V., and Olson, J. S. (2012a). How do hemeprotein sensors exclude oxygen? Lessons learned from cytochrome c', Nostoc puntiforme heme nitric oxide/oxygen-binding domain, and soluble guanylyl cyclase. Antioxid. Redox Signal. 17, 1246-1263. doi: 10.1089/ars.2012.4564

Tsai, E. J., Liu, Y., Koitabashi, N., Bedja, D., Danner, T., Jasmin, J. F., et al. (2012b). Pressure-overload-induced subcellular relocalization/oxidation of soluble guanylyl cyclase in the heart modulates enzyme stimulation. Circ. Res. 110, 295-303. doi: 10.1161/CIRCRESAHA.111.259242

Tsao, P. W., and Mousa, S. A. (1995). Thrombospondin mediates calcium mobilization in fibroblasts via its Arg-Gly-Asp and carboxyl-terminal domains. J. Biol. Chem. 270, 23747-23753. doi: 10.1074/jbc.270.40.23747

Underbakke, E. S., Iavarone, A. T., and Marletta, M. A. (2013). Higher-order interactions bridge the nitric oxide receptor and catalytic domains of soluble guanylate cyclase. Proc. Natl. Acad. Sci. U.S.A. 110, 6777-6782. doi: 10.1073/pnas.1301934110

Venema, R. C., Venema, V. J., Ju, H., Harris, M. B., Snead, C., Jilling, T., et al. (2003). Novel complexes of guanylate cyclase with heat shock protein 90 and nitric oxide synthase. Am. J. Physiol. Heart Circ. Physiol. 285, H669-H678. doi: 10.1152/ajpheart.01025.2002

Vernon-Wilson, E. F., Kee, W. J., Willis, A. C., Barclay, A. N., Simmons, D. L., and Brown, M. H. (2000). CD47 is a ligand for rat macrophage membrane signal regulatory protein SIRP (OX41) and human SIRPalpha 1. Eur. J. Immunol. 30, 2130-2137. doi: 10.1002/1521-4141(2000)30:8\%3C2130::AIDIMMU2130\%3E3.0.CO;2-8

Voetsch, B., Jin, R. C., and Loscalzo, J. (2004). Nitric oxide insufficiency and atherothrombosis. Histochem. Cell Biol. 122, 353-367. doi: 10.1007/s00418-0040675-z

Vogel, T., Guo, N. H., Krutzsch, H. C., Blake, D. A., Hartman, J., Mendelovitz, S., et al. (1993). Modulation of endothelial cell proliferation, adhesion, and motility by recombinant heparin-binding domain and synthetic peptides from the type I repeats of thrombospondin. J. Cell. Biochem. 53, 74-84. doi: 10.1002/jcb.240530109

Wang, X. Q., and Frazier, W. A. (1998). The thrombospondin receptor CD47 (IAP) modulates and associates with alpha2 beta1 integrin in vascular smooth muscle cells. Mol. Biol. Cell 9, 865-874. doi: 10.1091/mbc.9.4.865

Wedel, B., Humbert, P., Harteneck, C., Foerster, J., Malkewitz, J., Bohme, E., et al. (1994). Mutation of His-105 in the beta 1 subunit yields a nitric oxideinsensitive form of soluble guanylyl cyclase. Proc. Natl. Acad. Sci. U.S.A. 91, 2592-2596. doi: 10.1073/pnas.91.7.2592

Weinert, E. E., Phillips-Piro, C. M., Tran, R., Mathies, R. A., and Marletta, M. A. (2011). Controlling conformational flexibility of an $\mathrm{O}(2)$-binding H-NOX domain. Biochemistry 50, 6832-6840. doi: 10.1021/bi200788x

Weinert, E. E., Plate, L., Whited, C. A., Olea, C., and Marletta, M. A. Jr. (2010). Determinants of ligand affinity and heme reactivity in H-NOX domains. Angew. Chem. Int. Ed. Engl. 49, 720-723. doi: 10.1002/anie.200904799

Weitzberg, E., and Lundberg, J. O. (2013). Novel aspects of dietary nitrate and human health. Annu. Rev. Nutr. 33, 129-159. doi: 10.1146/annurev-nutr071812-161159

Whiteman, M., and Moore, P. K. (2009). Hydrogen sulfide and the vasculature: a novel vasculoprotective entity and regulator of nitric oxide bioavailability? J. Cell. Mol. Med. 13, 488-507. doi: 10.1111/j.1582-4934.2009.00645.x

Wilkinson, B., Koenigsknecht-Talboo, J., Grommes, C., Lee, C. Y., and Landreth, G. (2006). Fibrillar beta-amyloid-stimulated intracellular signaling cascades require Vav for induction of respiratory burst and phagocytosis in monocytes and microglia. J. Biol. Chem. 281, 20842-20850. doi: 10.1074/jbc.M600627200

Winger, J. A., Derbyshire, E. R., Lamers, M. H., Marletta, M. A., and Kuriyan, J. (2008). The crystal structure of the catalytic domain of a eukaryotic guanylate cyclase. BMC Struct. Biol. 8:42. doi: 10.1186/1472-6807-8-42

Winger, J. A., and Marletta, M. A. (2005). Expression and characterization of the catalytic domains of soluble guanylate cyclase: interaction with the heme domain. Biochemistry 44, 4083-4090. doi: 10.1021/bi047601d
Winter, M. B., Herzik, M. A. Jr., Kuriyan, J., and Marletta, M. A. (2011). Tunnels modulate ligand flux in a heme nitric oxide/oxygen binding (H-NOX) domain. Proc. Natl. Acad. Sci. U.S.A. 108, E881-E889. doi: 10.1073/pnas.11140 38108

Wu, S., Moore, T. M., Brough, G. H., Whitt, S. R., Chinkers, M., Li, M., et al. (2000). Cyclic nucleotide-gated channels mediate membrane depolarization following activation of store-operated calcium entry in endothelial cells. J. Biol. Chem. 275, 18887-18896. doi: 10.1074/jbc.M002795200

Wu, X. B., Brune, B., von Appen, F., and Ullrich, V. (1992). Reversible activation of soluble guanylate cyclase by oxidizing agents. Arch. Biochem. Biophys. 294, 75-82. doi: 10.1016/0003-9861(92)90139-N

Wykes, V., and Garthwaite, J. (2004). Membrane-association and the sensitivity of guanylyl cyclase-coupled receptors to nitric oxide. Br. J. Pharmacol. 141, 1087-1090. doi: 10.1038/sj.bjp.0705745

Xi, G., Shen, X. C., Wai, C., and Clemmons, D. R. (2013). Recruitment of Nox4 to a plasma membrane scaffold is required for localized reactive oxygen species generation and sustained Src activation in response to insulinlike growth factor-I. J. Biol. Chem. 288, 15641-15653. doi: 10.1074/jbc.M113. 456046

Yao, M., Roberts, D. D., and Isenberg, J. S. (2011). Thrombospondin-1 inhibition of vascular smooth muscle cell responses occurs via modulation of both cAMP and cGMP. Pharmacol. Res. 63, 13-22. doi: 10.1016/j.phrs.2010.10.014

Yao, M., Rogers, N. M., Csanyi, G., Rodriguez, A. I., Ross, M. A., St. Croix, C., et al. (2014). Thrombospondin-1 activation of signal-regulatory protein-alpha stimulates reactive oxygen species production and promotes renal ischemia reperfusion injury. J. Am. Soc. Nephrol. doi: 10.1681/ASN.2013040433. [Epub ahead of print].

Zabel, U., Hausler, C., Weeger, M., and Schmidt, H. H. (1999). Homodimerization of soluble guanylyl cyclase subunits. Dimerization analysis using a glutathione s-transferase affinity tag. J. Biol. Chem. 274, 18149-18152. doi: 10.1074/jbc. 274.26 .18149

Zabel, U., Kleinschnitz, C., Oh, P., Nedvetsky, P., Smolenski, A., Muller, H., et al. (2002). Calcium-dependent membrane association sensitizes soluble guanylyl cyclase to nitric oxide. Nat. Cell Biol. 4, 307-311. doi: 10.1038/ ncb775

Zhao, Y., Brandish, P. E., Ballou, D. P., and Marletta, M. A. (1999). A molecular basis for nitric oxide sensing by soluble guanylate cyclase. Proc. Natl. Acad. Sci. U.S.A. 96, 14753-14758. doi: 10.1073/pnas.96.26.14753

Zhao, Y., Brandish, P. E., Di Valentin, M., Schelvis, J. P., Babcock, G. T., and Marletta, M. A. (2000). Inhibition of soluble guanylate cyclase by ODQ. Biochemistry 39, 10848-10854. doi: 10.1021/bi9929296

Zhou, Z., Sayed, N., Pyriochou, A., Roussos, C., Fulton, D., Beuve, A., et al. (2008). Protein kinase G phosphorylates soluble guanylyl cyclase on serine 64 and inhibits its activity. Arterioscler. Thromb. Vasc. Biol. 28, 1803-1810. doi: 10.1161/ATVBAHA.108.165043

Zwiller, J., Revel, M. O., and Basset, P. (1981). Evidence for phosphorylation of rat brain guanylate cyclase by cyclic AMP-dependent protein kinase. Biochem. Biophys. Res. Commun. 101, 1381-1387. doi: 10.1016/0006-291X(81) 91600-4

Conflict of Interest Statement: Jeffrey S. Isenberg is Chair of the Scientific Advisory Boards of Vasculox, Inc. (St. Louis, MO) and Radiation Control Technologies, Inc. (RCTI, NY, NY) and holds equity interest in the same. The authors declare that the research was conducted in the absence of any commercial or financial relationships that could be construed as a potential conflict of interest.

Received: 22 January 2014; accepted: 18 March 2014; published online: 04 April 2014. Citation: Rogers NM, Seeger F, Garcin ED, Roberts DD and Isenberg JS (2014) Regulation of soluble guanylate cyclase by matricellular thrombospondins: implications for blood flow. Front. Physiol. 5:134. doi: 10.3389/fphys.2014.00134

This article was submitted to Vascular Physiology, a section of the journal Frontiers in Physiology.

Copyright (C) 2014 Rogers, Seeger, Garcin, Roberts and Isenberg. This is an openaccess article distributed under the terms of the Creative Commons Attribution License (CC BY). The use, distribution or reproduction in other forums is permitted, provided the original author(s) or licensor are credited and that the original publication in this journal is cited, in accordance with accepted academic practice. No use, distribution or reproduction is permitted which does not comply with these terms. 